\title{
STRUCTURAL DAMAGE ASPECTS OF THE APRIL 22, 1991 COSTA RICA EARTHQUAKE
}

\author{
M. J. Nigel Priestley 1
}

\begin{abstract}
SUMMARY
The magnitude $M=7.4$ earthquake of April 22, 1991 occurred in a comparatively lightly inhabited region of Costa Rica. Despite dramatic geomorphological effects, including extensive landslides in the mountainous epicentral region, and uplift of the East Coastline by up to $1.5 \mathrm{~m}$, structural damage was comparatively light. A number of warehouses, and reinforced concrete buildings in or near the Port of Limón collapsed or were badly damaged, and a considerable number of houses supported on tall wooden piles failed. Of greatest interest was the failure of a number of modern highway bridges, due primarily to liquefaction of foundations, or excessive movement of soft soil layers in embankments.
\end{abstract}

\section{INTRODUCTION}

Costa Rica is located in the isthmus between Central and South America, in a region of moderately active seismicity, caused primarily by tectonic action involving subduction of the Cocos Plate to the west of Costa Rica under the Caribbean Plate which contains all of Costs Rica. Major earthquakes at depths of 50$100 \mathrm{~km}$ are thus possible, located near the west coast of the country. Further secondary earthquakes occur along the volcanic arc of mountains that form the North-South spine of the country. These are generally smaller in magnitude, and occur at lesser depths than the subduction earthquakes.

The $\mathbf{M}=7.4$ earthquake of April 22, 1991, locally termed the Talamanca earthquake after the mountainous epicentral region, falls into the second category of earthquake, but occurred east of the volcanic arc in a location felt to pose comparatively low seismic risk, despite evidence, both geographic and anecdotal, of a significant earthquake there in the early part of the 20th century. Fig. 1 locates the epicentre $\left(9^{\circ} 38.6^{\prime} \mathrm{N}, 84^{\circ} 5.9^{\prime} \mathrm{W}\right)$ and gives an approximate indication of the surface projection of the fault plate. The fault movement has been characterized as a reverse thrust faulting with the east block moving upwards. ${ }^{(1)}$ The focal depth is estimated at about $21 \mathrm{~km}$. Eight accelerographs were triggered by the earthquake; none close to the epicentre. A maximum recorded acceleration of $0.27 \mathrm{~g}$ has been reported from an accelerograph at Cartago, about $90 \mathrm{~km}$ from the epicentre. At this station the duration of ground shaking was about 35 seconds.

The epicentral region is sparsely populated by native Costa Ricans who live an isolated life in simple wooden structures, and have little contact with the more developed parts of the Costa Rican community and economy. It is a heavily forested region with steep ridges and high rainfall, susceptible to land-

${ }^{1}$ Professor, University of California, San Diego, USA.

(Fellow and Past President) slides. Although many landslides did occur (see Fig.2, for example) temporarily damming a number of rivers, the effects were not as serious as might be expected, due to a fortuitously and uncharacteristically dry spell of weather preceding the earthquake. Normally the rainy season has set in by early April, with the water-saturated surface layers being much less stable than was in fact the case.

Uplift of the east block of the affected region resulted in the coastline in the vicinity of Limón (see Fig.1) being raised by some 1 to $1.5 \mathrm{~m}$. This caused some minor problems at the adjacent ports of Puerto Limón and Puerto Moin because of reduced draft clearance, but shipping operations were able to continue almost uninterrupted. This was fortunate, since Limón is the centre for export of the economically important banana crop, and the coastal terminal of the oil pipeline supplying San Jose, the capital of Costa Rica. Figs. 3 and 4 show evidence of the uplifted coastline in the region of Limón.

Puerto Moin is also the southern end of the shallow Tortuegas Canal, which runs parallel and close to the coast, north into Nicaragua. This major tourist attraction, famous for the wild life visible on the banks was rendered impassable over most of its length by the uplifting of the region. During the earthquake the uplifting action caused a minor tsunami, which flowed up the canal, tearing boats from their moorings, then flowing out to sea again, stranding boats (Fig.5) and destroying a dike (Fig.6). Before the earthquake, the boat visible in Fig.5 was moored at the wharf to the left of the picture. The dike in Fig. 6 was about 2-3 $\mathrm{m}$ high and carried a small road out to its seaward end. Water flowing down the canal was under normal condi-tions diverted round a curve by the canal, possibly to avoid silting of the Port of Moin, but the outsurge of the tsunami chose the more direct route up, over and through the dike, and into the port region.

The provisional death toll from the earthquake is 47 , with 198 injuries requiring hospital attention. More than a thousand houses were destroyed, and a similar number severely damaged. 


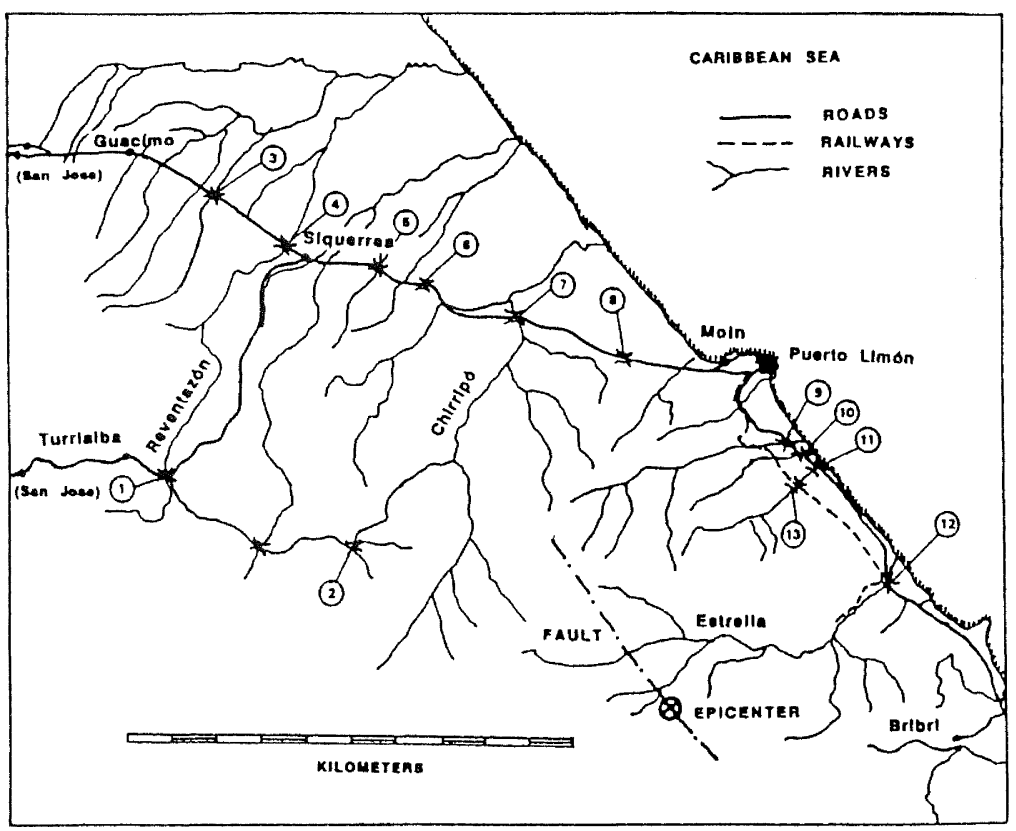

FIGURE 1: Location of Epicentre and Sites of Damage.

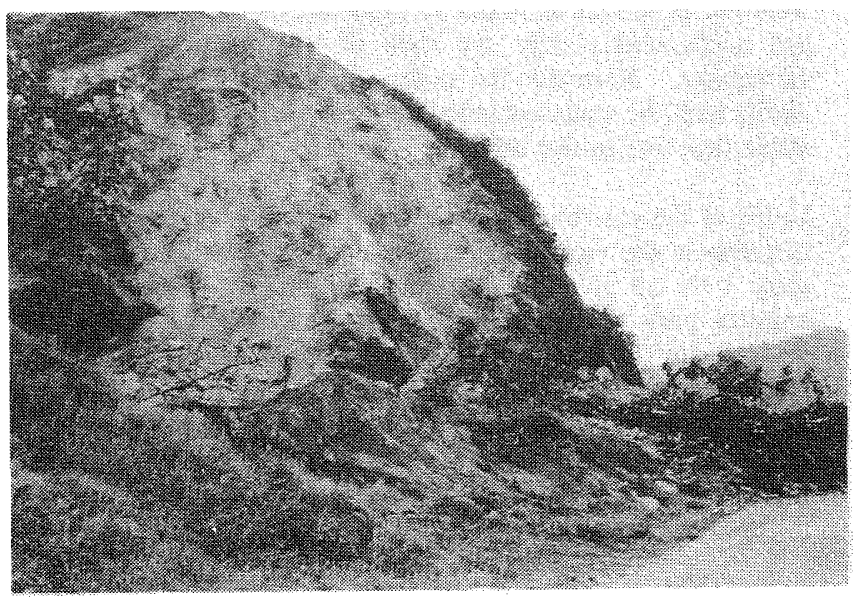

FIGURE 2: Landslide Near Epicentral Region.

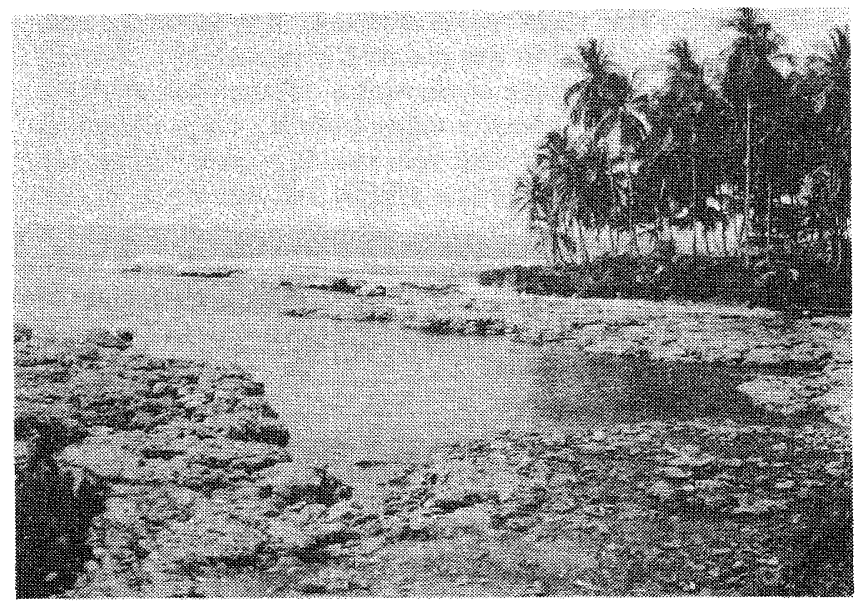

FIGURE 3: Uplifted Shoreline at Moin (note former tidal line on rocks). 


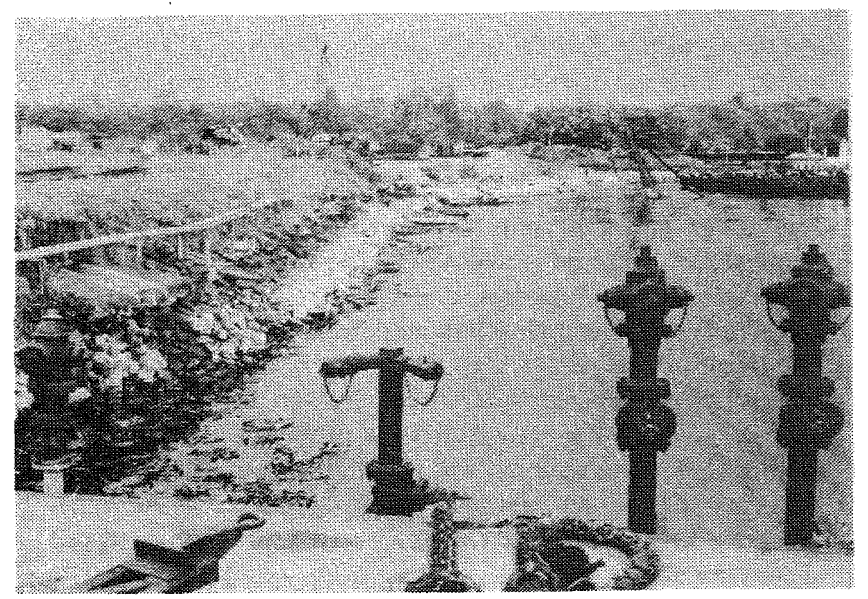

FIGURE 4: Uplifted Coral Beds in Puerto Limón.

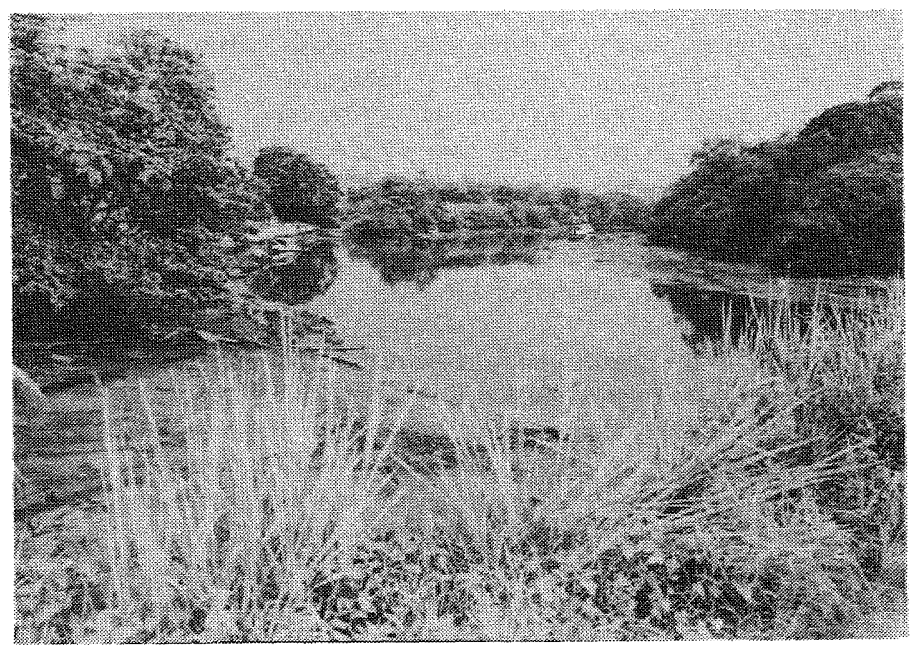

FIGURE 5: Beached Boats at Mouth of Tortuegas Canel (Moin).

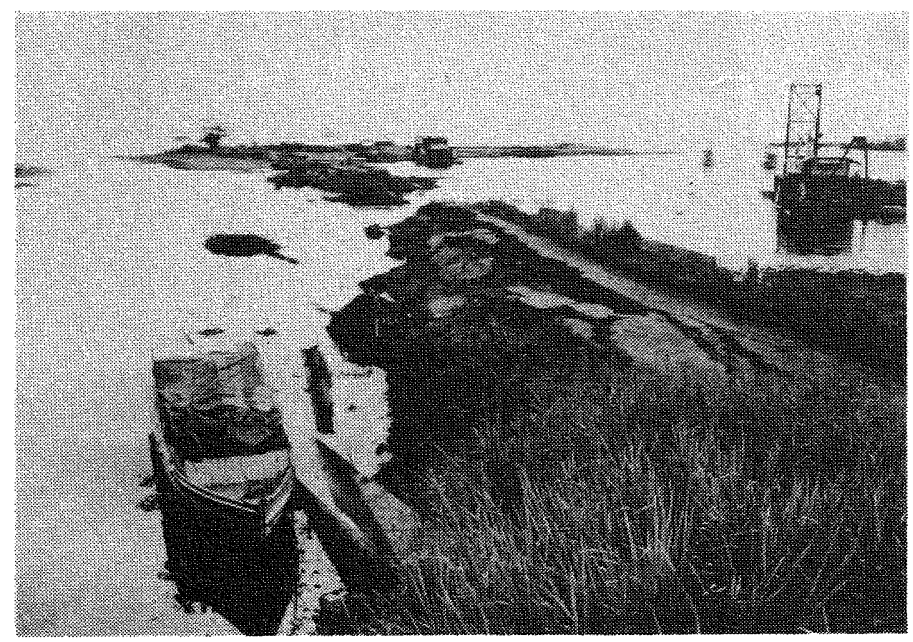

FIGURE 6: Dike Destroyed by Outflow of Water from Tortuegas Canel, Following Upsurge into Canel. 
The author was part of a reconnaissance team sent by the Earthquake Engineering Research Institute to provide a quick initial report on the effects of the earthquake. He had special responsibility for reporting on damage to bridges, and assisted others of the team with investigation of general structural damage. The remainder of this paper is therefore directed towards structural aspects of the damage, based on a 6 day visit one week after the earthquake. The above general description of the earthquake and its geomorphological effects is subjective, and necessarily incomplete, and the interested reader is referred elsewhere ${ }^{(1)}$ for more detailed information, and for information on such topics as social aspects of the earthquake, which are not considered at all herein.

\section{STRUCTURAL DAMAGE}

Damage to engineered structures in the Talamanca earthquake included failure of roading embankments, collapse or damage of road and rail bridges, and damage or failure of a variety of buildings, including hotels, factories and warehouses. Although the first category is outside the area of specialization of the writer, the damage was so dramatic that at least a cursory mention is deserved.

\section{Damage to Roading Embankments}

The material of the coastal plains in the region of strong ground motion tends to be unconsolidated silty sands with a high water table, and a natural propensity for liquefaction. In the stretch of the main road from Siquerres to Puerto Limón, and south towards Bribri (see Fig.1), a modern road was constructed on embankments typically 1-2 m above grade, with the embankment height rising to as much as $4-5 \mathrm{~m}$ in the approaches to major bridges. Liquefaction of the soils supporting the embankments caused sinking and spreading of the embankments, with forma-tion of cracks parallel to the road axis. North of Limón, these cracks were substantial (see Fig.7) but were quickly repaired by gravel fill. South of Limón, and thus closer to the fault region, the damage was more dramatic, and occasionally spectacular, as evidenced by Fig. 8 which shows the condition of the south approach embankment to the Estrella River bridge (12, Fig.1), which suffered deep fissures, and settlement of up to $2 \mathrm{~m}$.

\section{Damage to Bridges}

The most dramatic expression of the destructive power of the earthquake is provided by the extensive and widespread damage to bridges. Almost without exception, bridge damage could be related to soils effects; liquefaction and slumping; rather than vibrational effects.

Fig. 1 shows the location of major bridge damage relative to the epicentre and inferred fracture plane. The reconnaissance was primarily limited to the two major highways between San José and Bribri, near the Panamanian border, via Puerto Limón. On the older, southern route between San José and Siquerres, there was essentially no damage. One bridge (marked 1 on Fig.1) over the Rio Reventazón showed minor damage of curbs due to pounding at an internal movement joint, and was the only bridge on this route with damage apparent under the rapid surveillance made. A side trip through La Suiza to Grano de Oro, a high plane at about $1300 \mathrm{~m}$ near the inferred rupture plane also revealed very little bridge damage. Bridges on this route were primarily short single-span slab bridges on solid concrete abutments, with alluvial approach material including large gravel and rocks, rather than the sands and silts common in the coastal region. Two one-lane suspension bridges of approximately $50 \mathrm{~m}$ spans, one quite close to the fault plane (2 Fig.1) also appeared completely undamaged.

The newer northern route from San José to Siquerres was completed in 1986 and includes several major bridges, as do the sections between Siquerres and Puerto Limón and Bribri. Between San José and Guácimo no damage was observed. The first sign of damage to bridging was observed to a 3-span prestressed concrete-beam bridge over the Rio Destierro $75 \mathrm{~km}$ NW of Limón (3 Fig.1), where about $80 \mathrm{~mm}$ settlement of the south abutment fill material was noted (Fig.9a). The abutment was founded on an elevated embankment. At the same abutment, keeper-angle lateral supports (Fig.9b) were displaced under transverse response as a result of the inadequate anchorage provided by a short $30 \mathrm{~mm}$ diameter bolt, causing spalling of the concrete of the support block.

The bridge was of modern construction, with span lengths of about $30 \mathrm{~m}, 30 \mathrm{~m}, 25 \mathrm{~m}$, [North to South]. The superstructure consisted of five precast prestressed I girders with an in-situ deck. There was no continuity over the two interior supports which were tall $[30 \mathrm{~m}, 20 \mathrm{~m}$ respectively, North to South] single-column bents with the column diameter increasing with depth from the superstructure to a maximum of about $2 \mathrm{~m}$. These cantilever columns showed no visible signs of damage.

A major 5-span continuous prestressed concrete haunched segmental construction bridge of total length $32 \mathrm{~m}$ over the Rio Reventazón [4 Fig. 1] appeared undamaged, though one pier had a slight lean to the west. This appeared to have been a construction error rather than to have been earthquake related. The river bed material was largely medium-to-coarse alluvium, and the abutments were located in a cutting through the old walls of the river valley, rather than on fill embankments, as with the Rio Destierro bridge.

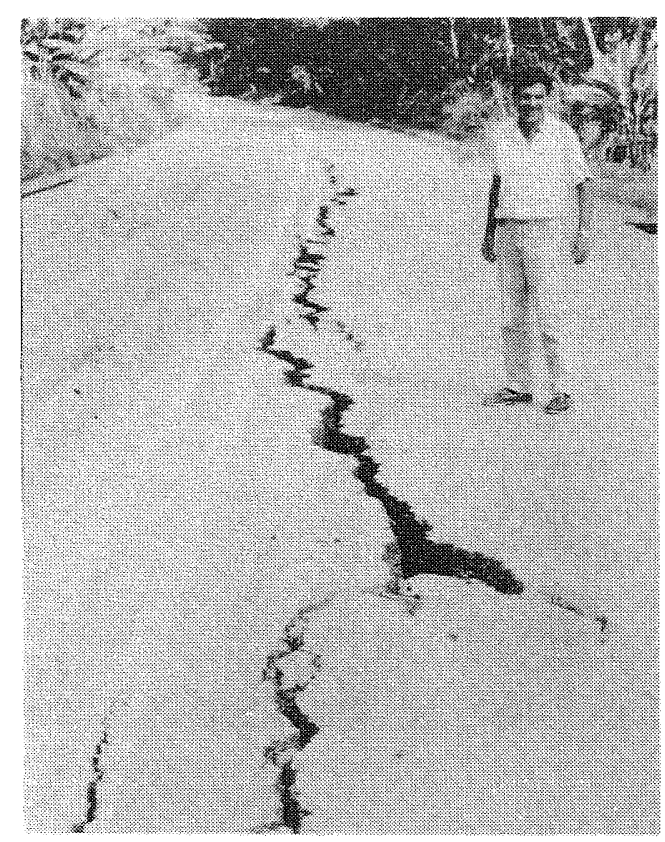

FIGURE 7: Typical Road Damage North of Limón, Caused by Abutment Spreading. 


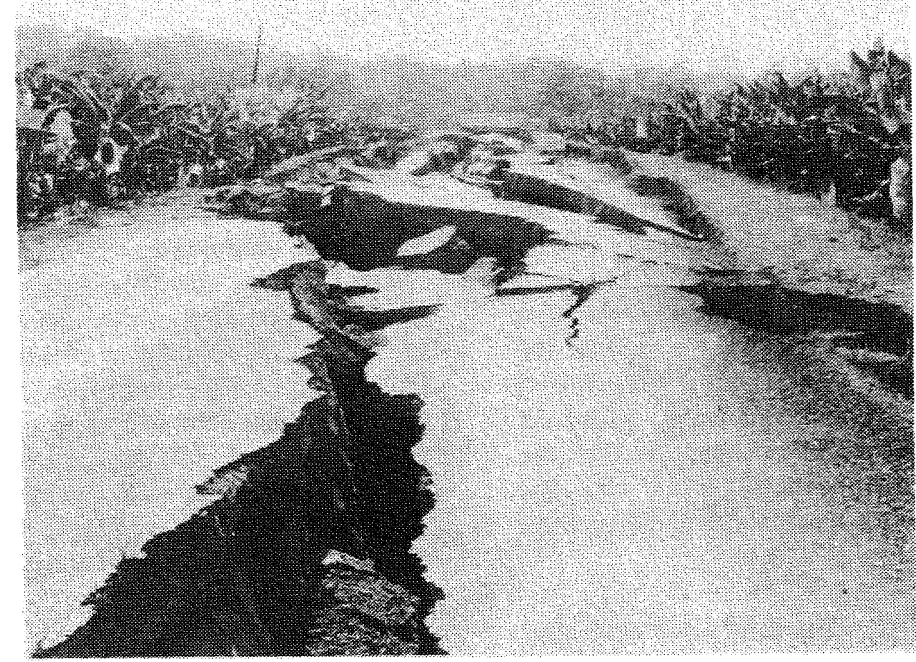

FIGURE 8: Extreme Damage to Embankment Approach to Rio Estrella Bridge.
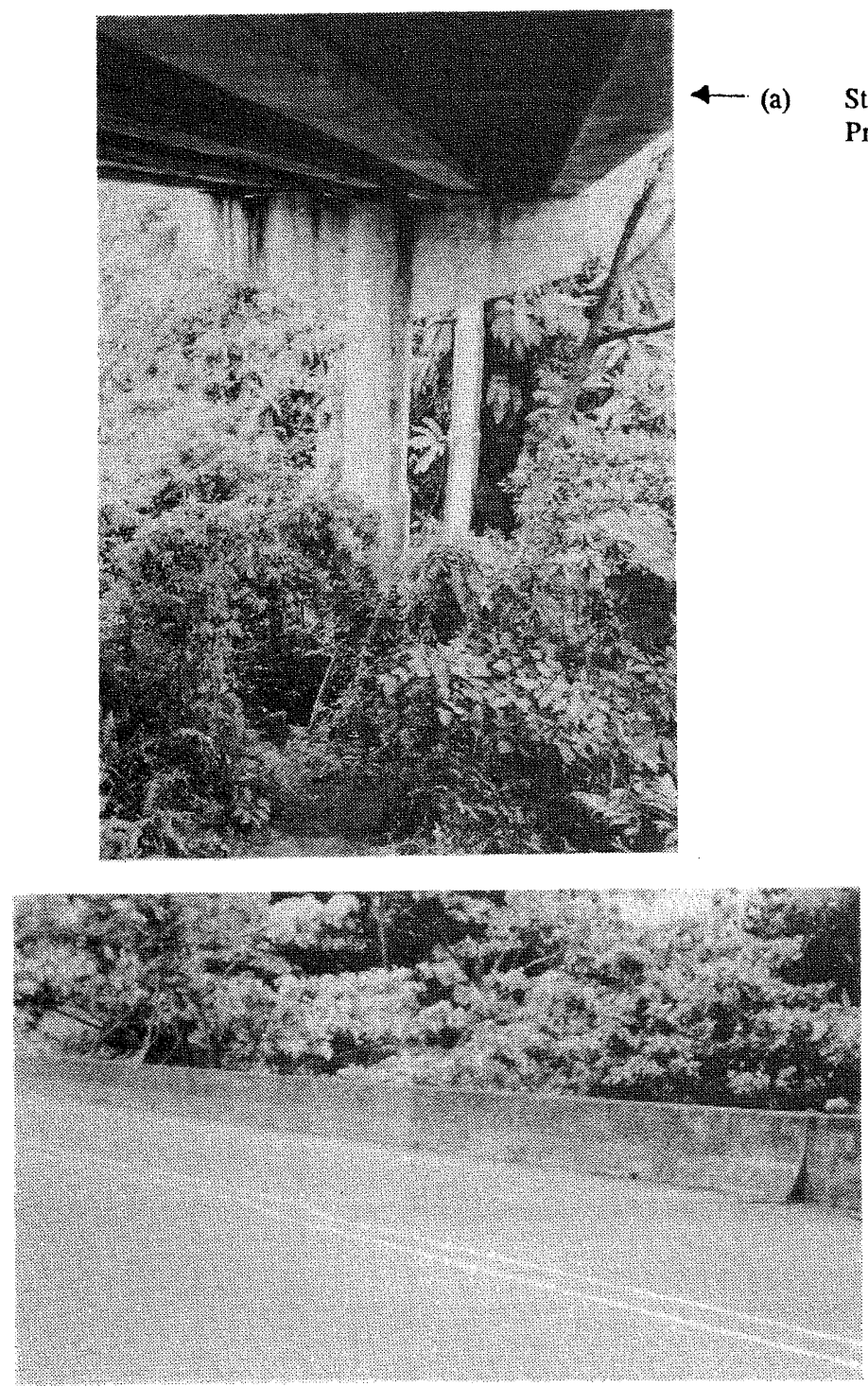

Structural Form: Simply Supported Precast I-Beams.

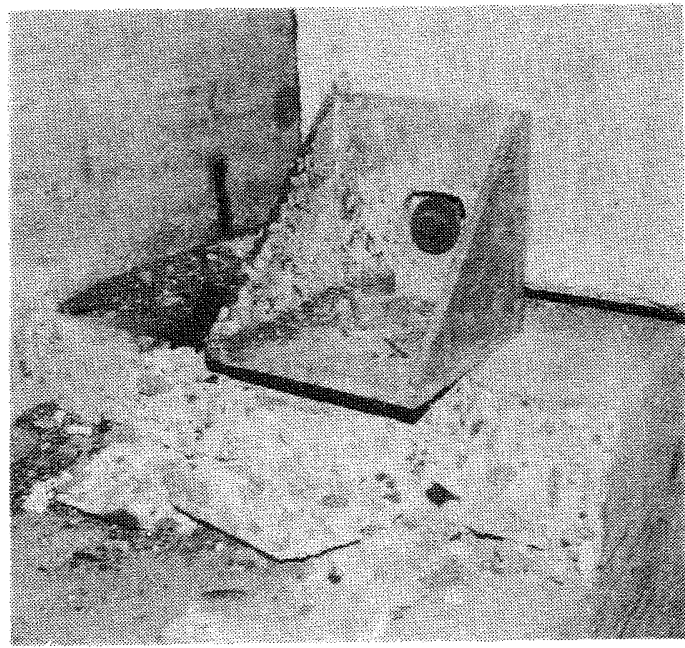

(b) Spalling of Abutment Support Block from Transverse Response.

- (c) Abutment Fill Settlement.

FIGURE 9: Damage to Rio Destierro Bridge (location 3 , Figure 1) 
At Rio Quebiero and Rio Aguas Claras (5,6, Fig. 1) about $40 \mathrm{~km}$ from Limón, short $(10 \mathrm{~m})$ single span slab-and-beam bridges crossed minor streams with the roadway on embankments 1-2 $\mathrm{m}$ above the surrounding countryside. At both bridges about $300 \mathrm{~mm}$ slumping of abutment fill material occurred, but the use of settlement slabs enabled them to remain serviceable, despite damage to concrete curbing (Fig.10). This seems to have been caused by a minor design defect, where the settlement slab was separated from the abutment wing walls, but the curb of the settlement slab beyond the abutment wing wall was integral with the settlement slab, but supported by the wing walls. Under fill settlement, this support resisted vertical displacement of the settlement slab, causing shear and bending. There was also evidence of pounding damage between abutments and the bridge spans.

The Chirripó bridge (7, Fig.1) was a six-span continuous steel plate girder bridge with a short south eastern-end land span of

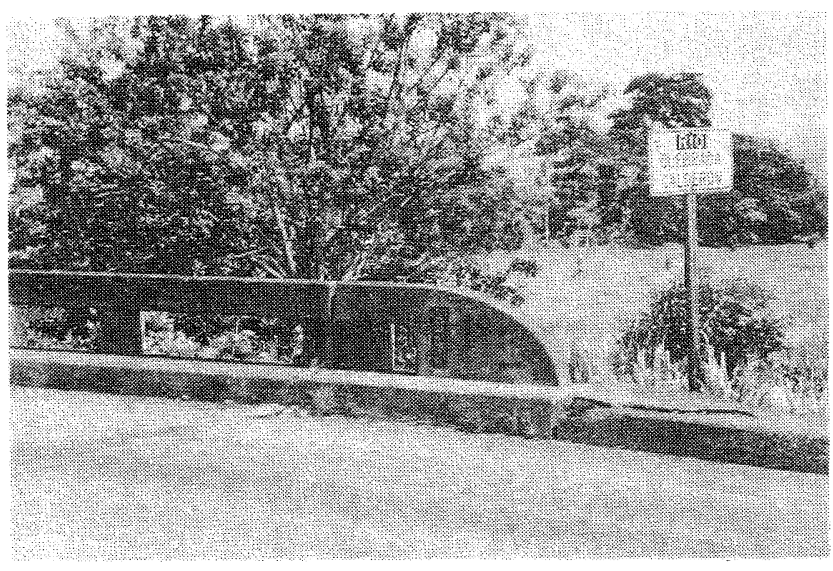

(a) Rio Quebrada Calderon Abutment Slumping $(300 \mathrm{~m})$. Note effectiveness of settlement slab, but damage to curb.
$15 \mathrm{~m}$ simply supported girders. The bent supporting the end of the continuous section, and the short land span of the bridge was supported on a pier wall. Fig.11 shows a general view of the bridge.

During the earthquake, the land span was dislodged from the internal support and fell. When the bridge was inspected six days after the earthquake, the collapsed span was buried in gravel to allow resumption of traffic, (Fig.11b), but it was clear that the internal pier wall had rotated towards the river. It is postulated that this was a result of abutment fill slumping, pushing the end span onto the internal span with some force, and causing the pier wall rotation apparent in Fig.11c. During subsequent response motion in the reverse direction, the end span unseated off the short support shelf.

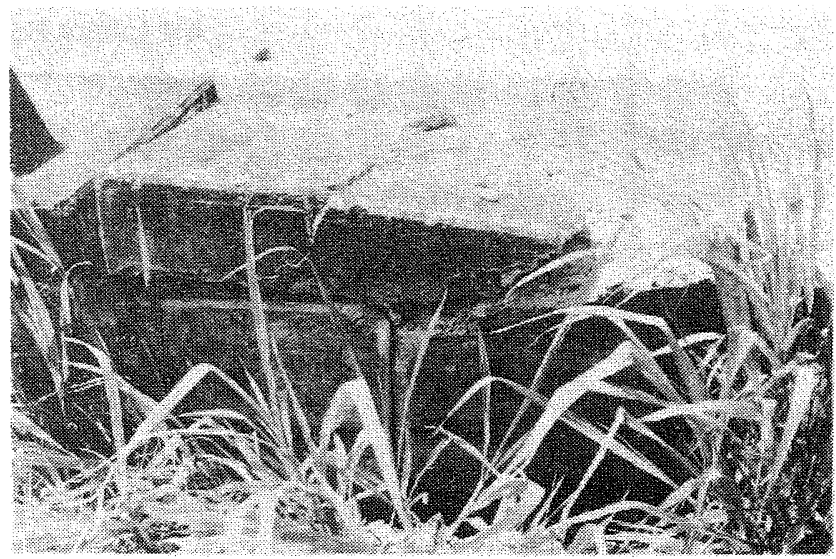

(b) Detail of above. Curb is integral with settlement slab but supported on abutment wing wall, causing failure when slab settles.

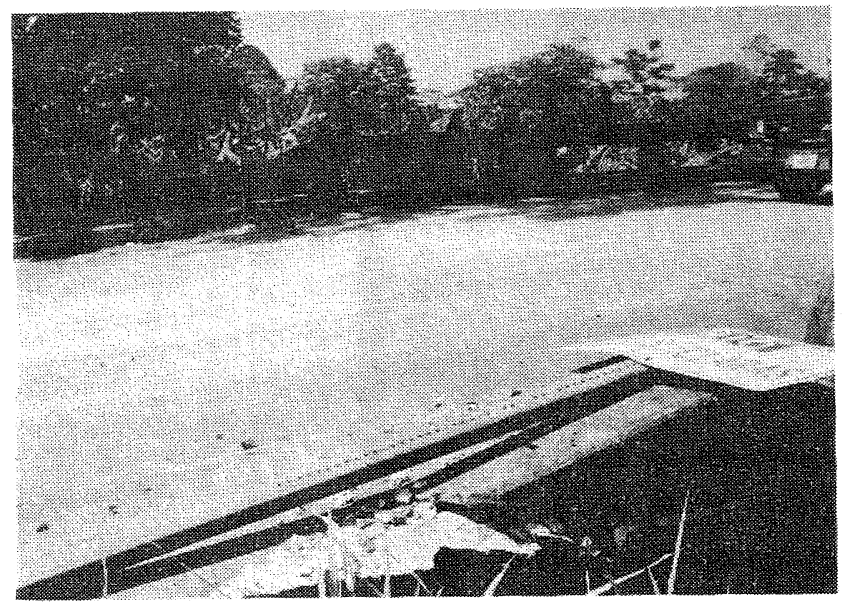

(c) Rio Aguas Claras. Same detail as above, with the same consequence.

FIGURE 10: Single Span P.C. I-Beam and Slab Bridges with Settlement Slabs (locations 5 and 6, Figure 1) 


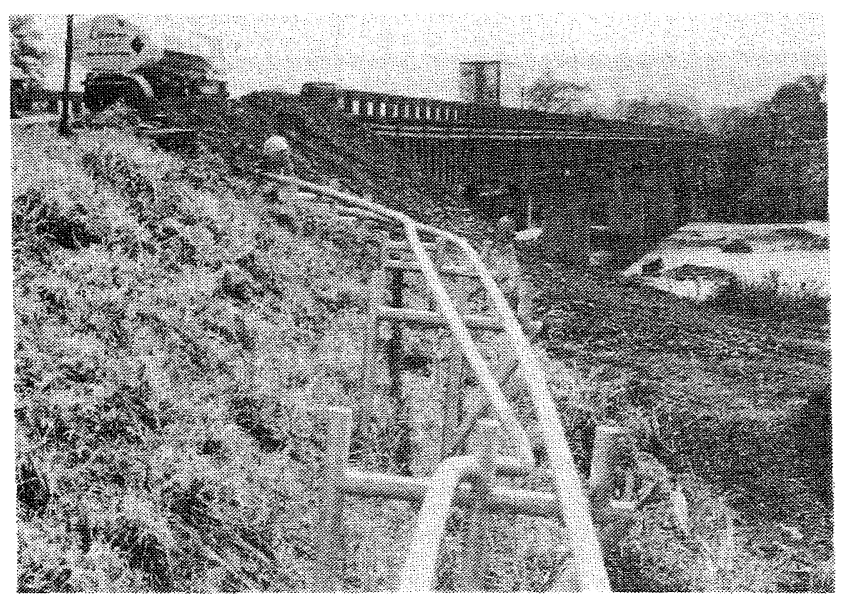

(a) General View with Buckled Oil Pipeline.

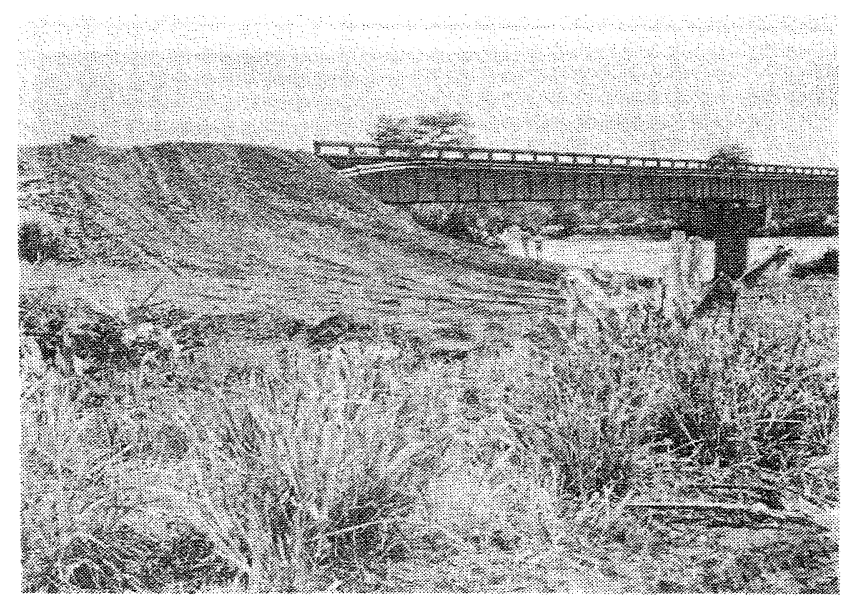

(b) Gravel Infilled over Fallen End-Span of Bridge (opened 6 days after earthquake).

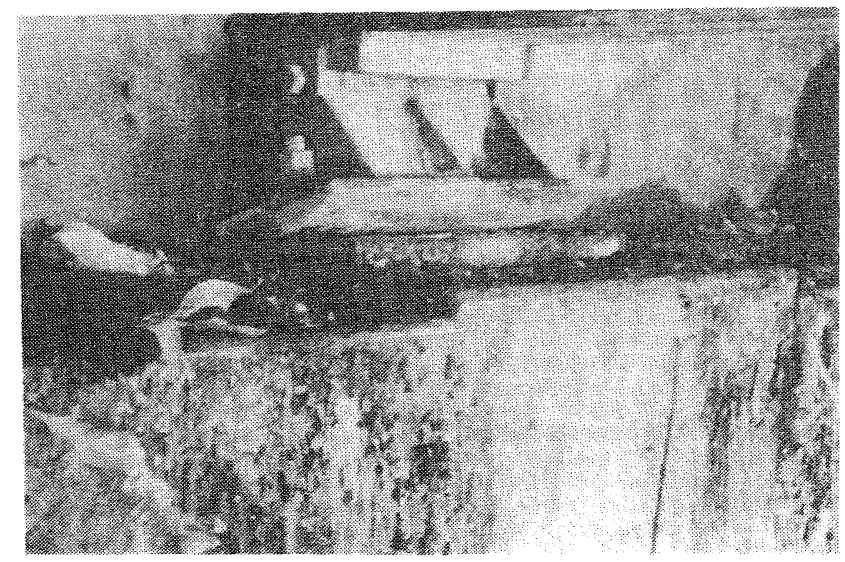

(c) Rotation of pier away from fallen end span, shown by rocker support rotation.

FIGURE 11: Damage to Rio Chirrpo Bridge (location 7, Figure 1).

Approaching closer to Limón, and hence closer to the near-field area, the earthquake effects were more apparent in terms of damage to housing, to roading embankments, and also to bridges. Of these the most significant was damage to a 3-span prestressed concrete beam and slab bridge at Rio Buffalo (8,Fig. 1) about $12 \mathrm{~km}$ from Limón. Spans were about $22 \mathrm{~m}$ long, and, as with most bridges in the area, were simply supported. This bridge suffered severe slumping of the abutment, apparently due to liquefaction of the bank material which flowed into the river. As is clear from Fig. 12a, the piles were founded in the mobile layer, since significant rotation of the abutment base towards the river occurred, without causing damage to the piles. At the interior piers, damage to girder seats (Fig. 12b) indicated significant transverse response.

The most dramatic bridge failures occurred south of Limón on the main road to Bribri. Most bridges between Limón and Rio Estrella on this route failed due to soil effects, or were severely damaged.
The Rio Banano Bridge (9, Fig. 1) is located in an area which suffered extensive liquefaction, with river bank material slumping and flowing several metres on near-horizontal slopes. The single-lane bridge consists of 3-22 m spans of two precast prestressed concrete I-girders plus an in-situ deck slab, with a shorter end span at the northern end. Fig.13a and b show general dimensions and a general view, looking North, including an internal pier. During the earthquake, the south abutment slope and fill material slumped about one metre, with movement towards the river. The abutment was restrained longitudinally at the top by the superstructure, causing a rotation of about $9^{\circ}$ of the abutment structure (Fig.13c). This resulted in an inward movement of about $660 \mathrm{~mm}$ at the top of the piles, which appear to have been adequately founded so that no slumping or lateral displacement of the pile tips occurred. The front batter piles [ $360 \mathrm{~mm}$ sq.] driven with a slope of 1:5, suffered shear and flexural failures, though the rear vertical piles were less severely damaged [Fig. 14d,e]. The piles were each reinforced 


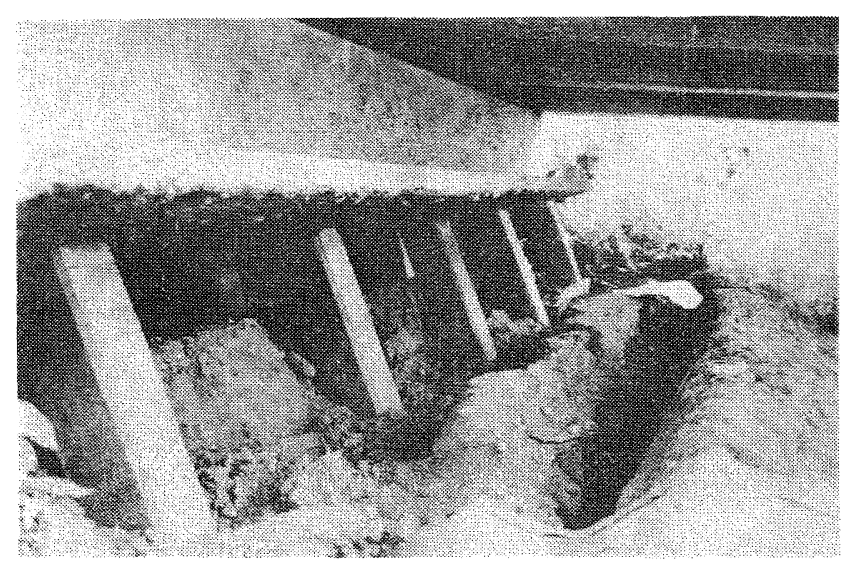

(a) Abutment rotation and foundation material slumping. Lack of damage to piles indicates the base of these have moved with the soil.

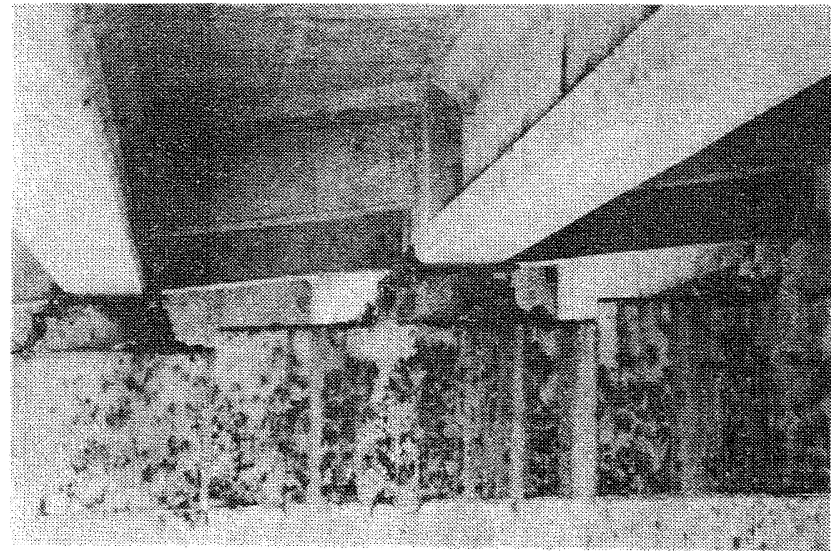

(b) Girder Seat Damage at Interior Pier.

FIGURE 12: Damage to Rio Buffalo Bridge (location 8, Figure 1).

with 4 \#6 [19 mm dia.] corner longitudinal bars, with \#2 $(6.4 \mathrm{~mm})$ transverse peripheral hoops at $150 \mathrm{~mm}$ centres. "Asbuilt" plans indicated a further $4 \# 6$ bars, one at the middle of each side, which appeared to have been victims of an economy drive by the contractor. Despite the extremely severe damage, and large lateral displacements sustained by these piles, it was of interest to the reconnaissance team that the bridge remained serviceable after the earthquake for emergency equipment, including a $\mathrm{D}-8$ bulldozer on a heavy transporter.

A classic example of liquefaction failure was provided by the collapse of the Rio Viscaya River bridge [10,Fig.1] founded on sands very close to the shore line of the Caribbean Sea. This bridge consisted of 3 simply-supported prestressed I-beam plus slab spans [21 m - 25 m-21 m] Fig.14a and b show general dimensions and the inferred failure mode. Fig. 15 shows photographs of the collapse. The interior supports were inadequately founded on the liquefiable layers, and both settled. At the southern interior pier (2, Fig.14a) a linkage restrainer anchored by bolts into the two adjacent spans (see Fig.15c) maintained the connection between the centre and south spans. The equivalent connection at pier 3 evidently failed, allowing this pier to rotate to the north. At the same time, the north abutment fill settled about $1 \mathrm{~m}$, rotating the base of the abutment towards the river, as seen in Fig. 15d. The northward rotation of pier 3 coupled with the north abutment slumping caused the northern bridge span to be driven through and over the end wall of the abutment as evident in Fig.15d. Note again the flexure/ shear failure of the piles, and the compression failure of a rear pile, shown in Fig.15e. A detail of a front pile is shown in Fig. 15f.

Some $4 \mathrm{~km}$ south of Rio Vizcaya, a two-span simply supported bridge at Rio Bananito (11,Fig.1) with abutments and central wall pier skewed at about $30^{\circ}$ to the transverse axis of the bridge lost support of both spans of the central pier. As shown in Fig.16, both spans fell in the direction of increasing skew. There did not appear to be evidence of settlement or rotation of the central pier. Failure seemed to be related to end abutment rotation, and fill slumping (Fig.16a) which caused the end scatings to move away from the central pier, with consequent loss of seating. Fig.16c shows an apparent compression shear failure of one of the prestressed I-girders. It is probable that this was caused by impact effects associated with the unseating of the spans. A further bridge at Estero Negro, a few $\mathrm{km}$ south of Rio Bananito was also apparently badly damaged, but was inaccessible to the reconnaissance team.

The final bridge observed on this route at Rio Estrella (12, Fig.1), involving a lengthy detour inland towards the epicentral area to find passable fords and bridges. Although closer to the epicentre, this route had less damage due to the somewhat better soil conditions inland. The south approach embankment of the Rio Estrella bridge displayed the extraordinary slumping apparent in Fig. 8. This bridge, shown schematically in Fig. 17 consisted of two $75 \mathrm{~m}$ spans of steel through-trusses, with a $22 \mathrm{~m}$ prestressed concrete I-girder span at the northern end. The south span unseated at the south abutment, and suffered a complex failure at the other end, as shown in Figs. 17 and 18. The bottom chords of the span failed at the base of the first tie south of the internal pier. The end diagonal remained connected to a transverse support beam which was bolted to the internal pier concrete by $4-40 \mathrm{~mm}$ bolts, and buckled when the tension chord failed. The failed tension chords, now hanging vertical, and the buckled end diagonals are clearly visible in Fig. 18. The north span pulled of the internal support, with buckling of the end section of the truss, apparent in Fig. $18 \mathrm{c}$ being caused by the impact associated with falling.

Since the steel truss spans were simply supported, and free to slide at one end, it is not clear how sufficient tension forces developed in the bottom chord to cause failure. It is possible that sliding bearings may have frozen due to rusting in the aggressive environment adjacent to the coast, or that some complex dynamic effects associated with vertical accelerations, or loss of seating at the south end induced failures.

The writer did not proceed further south. However, Caltrans employees on a parallel reconnaissance reported that though there was damage to bridges, mainly in the form of abutment rotation and minor pounding, there were no further collapses of highway bridges south of Rio Estrella. 


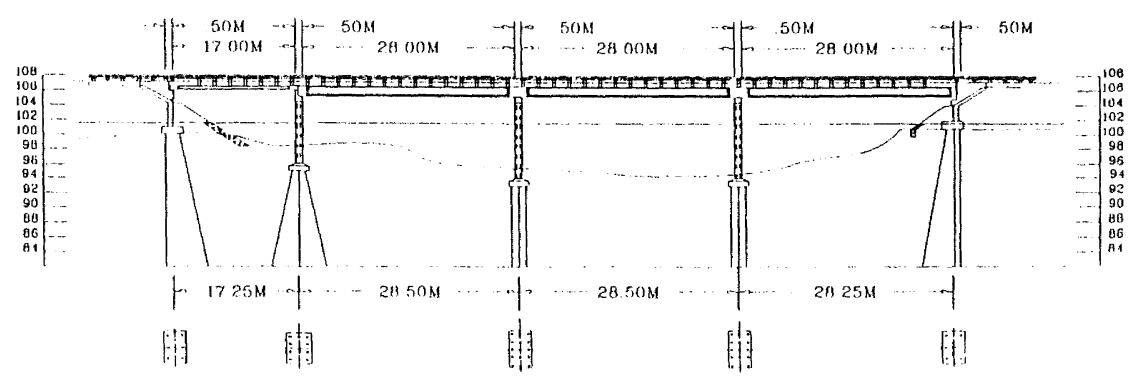

(a) General Dimensions of Bridge ${ }^{(1)}$.

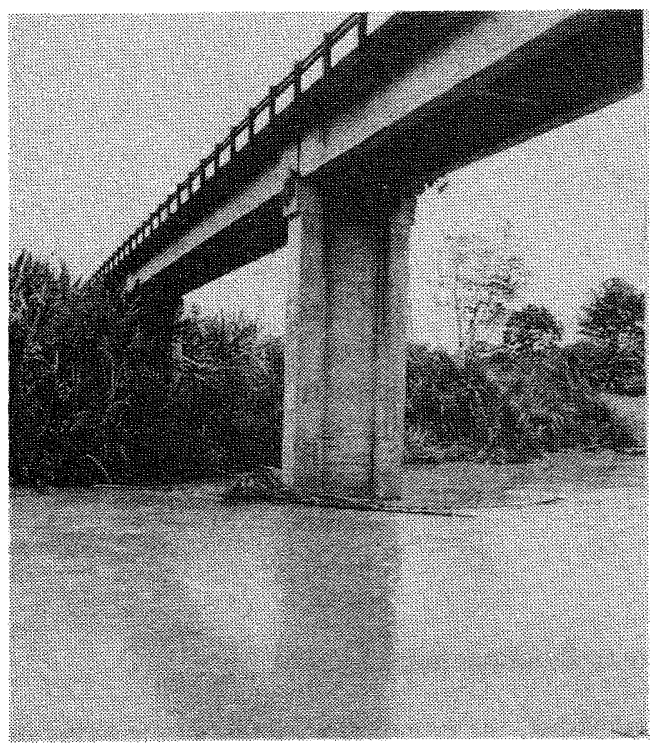

(b) General View of Bridge.

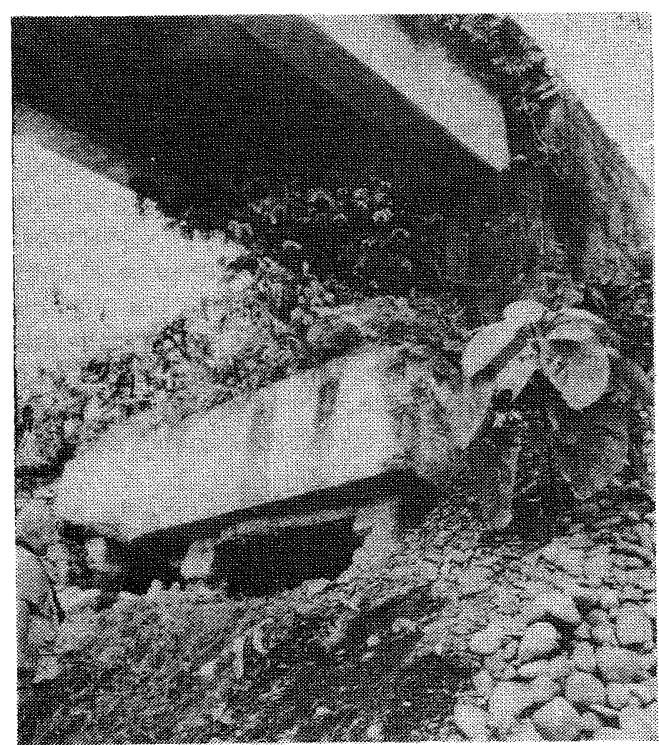

(d) Settlement and Pier Damage.

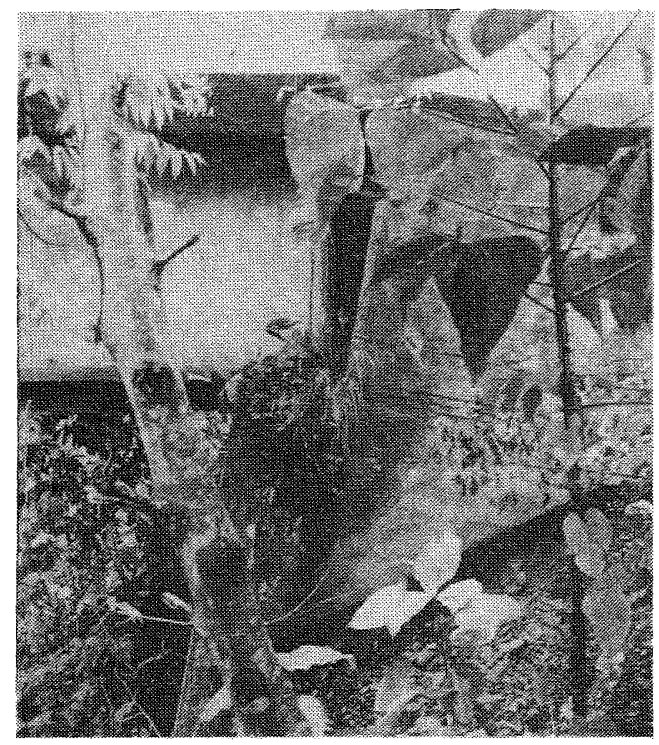

(c) Abutment Slumping and Rotation.

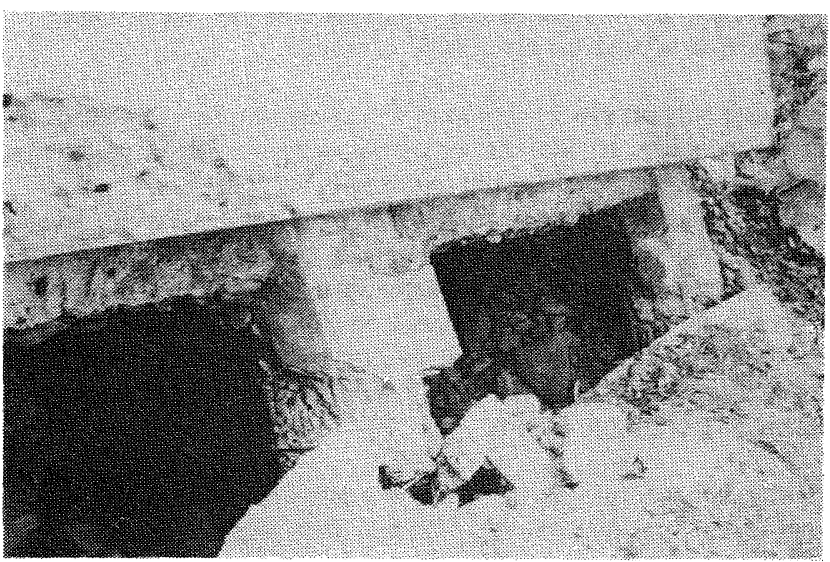

(e) Pile Failure (front raked piles were more heavily damaged than rear vertical piles).

FIGURE 13: Rio Banano Bridge (location 9, Figure 1). 


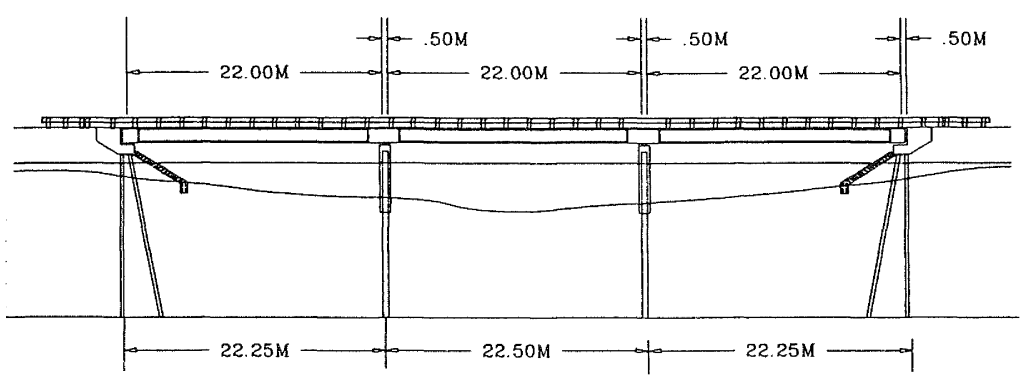

(a) General Dimensions ${ }^{(1)}$.

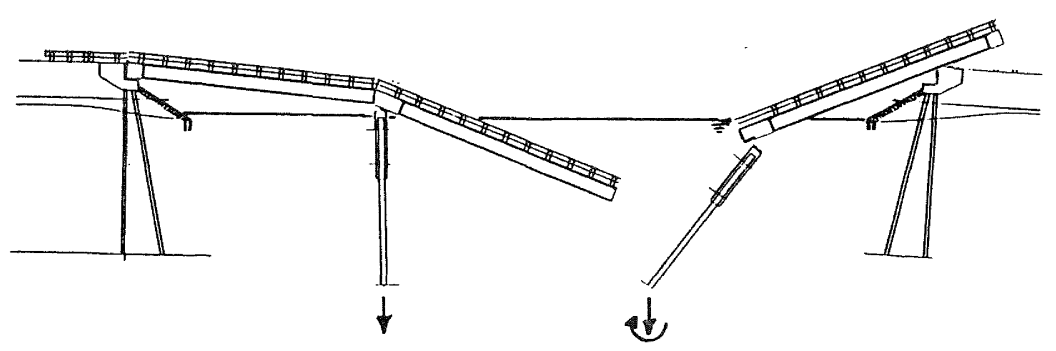

(b) Inferred Failure Mode.

FIGURE 14: Rio Viscaya Bridge - Dimensions and Failure Mode (location 10, Figure 1).

In the coastal region between Rio Estrella and Limón, then from Limón to San José, there is an old (approximately 100 year) narrow-gauge railway, used primarily for transport of bananas from the south to Limón, and formerly as a tourist train from San José to Limón. Because of difficulty of access to the rail bridges, the writer observed only one, a $50 \mathrm{~m}$ single-span through-truss over the Rio Bananito sur (13,Fig.1), supported at each end on $2.1 \mathrm{~m}$ dia. cast steel caissons filled with concrete. The surrounding area was subjected to significant ground movements as evidenced by buckled railway rails, and liquefaction of adjacent river bank material.

Concrete support blocks on top of the caissons were connected to the concrete of the caissons only with two short bolts. During the earthquake, the top of the caissons at each end of the bridge rotated towards the river, opening a wedge-shaped gap between the caissons and the support blocks, which were retained in their relative position by strut action of the bridge superstructure. The two downstream caissons rotated more than the upstream ones, allowing the support blocks to drop behind the caissons, thus tilting the bridge downstream. Fig.19 shows details of this bridge failure.

Similar damage was reported by others to a similar rail throughtruss on caissons over the Rio Chirripó at Matina, northwest of Limón.

\section{Damage to Buildings and Factories}

As stated earlier, the prime responsibility of the writer during the reconnaissance was to collect data relevant to bridge performance. However, as visits were made to a number of damaged buildings and factories, brief mention of these is provided in the following. Generally, engineered structures of any significance, apart from bridges, only existed within or in the immediate environs of Limón. Limón's foundation conditions appeared different from the surrounding regions, being largely comprised of coral rock, rather than unconsolidated sands, though a few locations with sands and silts of sufficient depth to cause ground movement problems were observed. As a consequence, perhaps, of the improved ground conditions, the performance of buildings at Limón was better than with bridges in the immediate vicinity. Although few buildings appeared to be designed to standards current in more developed areas, the fact that most buildings were only one to three stories also clearly had an impact on the comparative lack of damage.

Two hotels in Limón were extensively damaged: the Hotel International in downtown Puerto Limón, and the Hotel Las Olas, some $4 \mathrm{~km}$ north on the road to Puerto Moin. Both were reinforced concrete frame structures reputedly designed by the same engineer in about 1971 for the Hotel International, and 1976 for the Hotel Las Olas. 


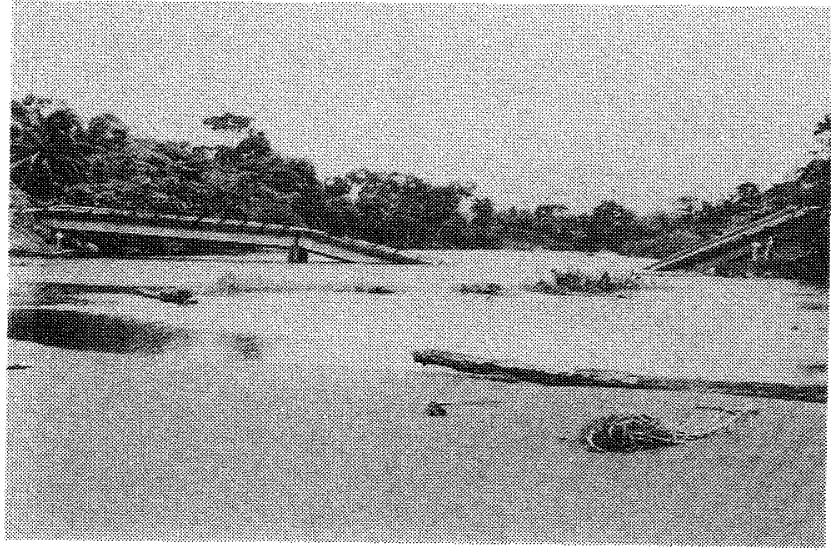

(a) General View

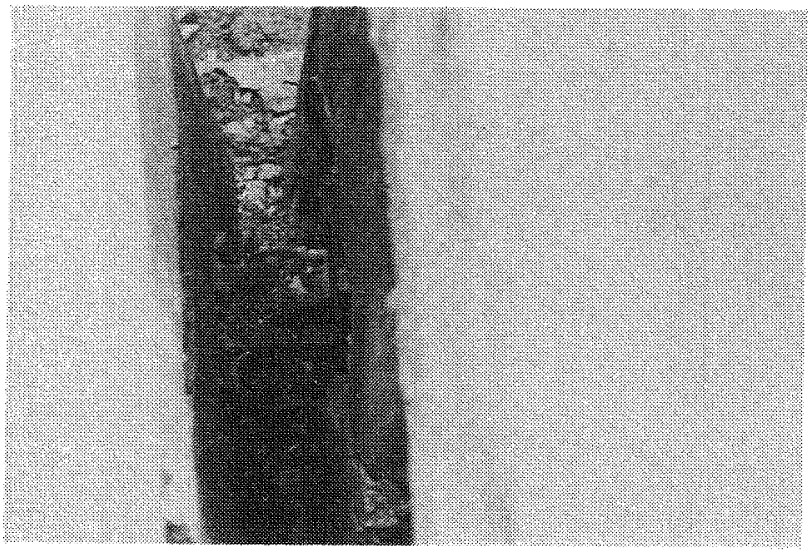

(c) Detail of Linkage Restrainer Connecting Spans over Pier 2.

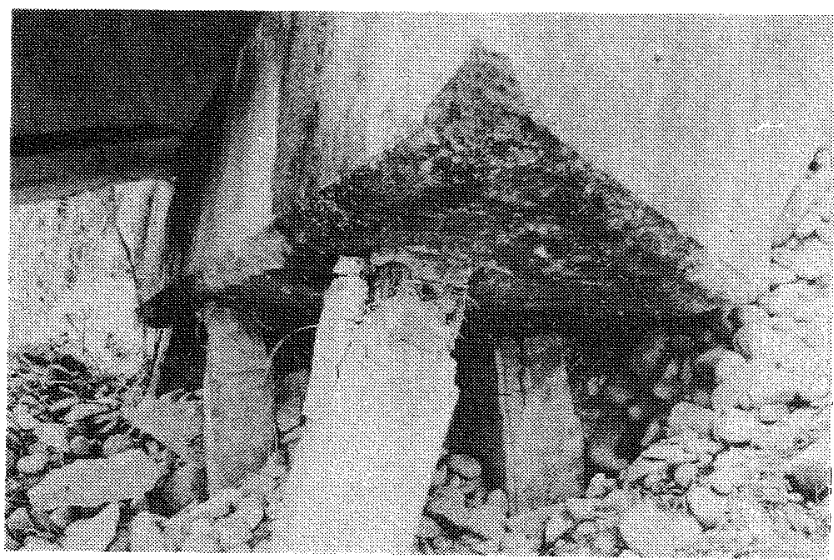

(e) Rotation of North Abutment and Pier Failure. Note compression failure of rear pile.

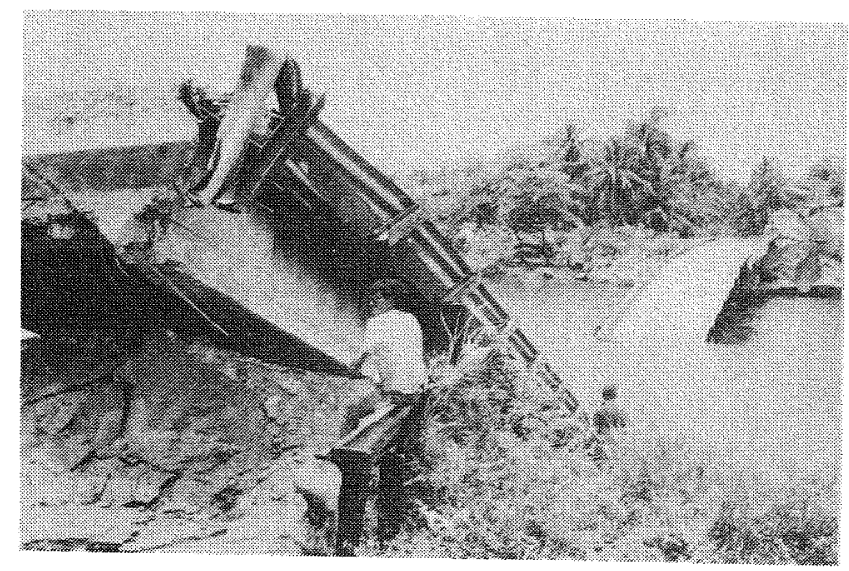

(b) General View showing North Abutment Damage.

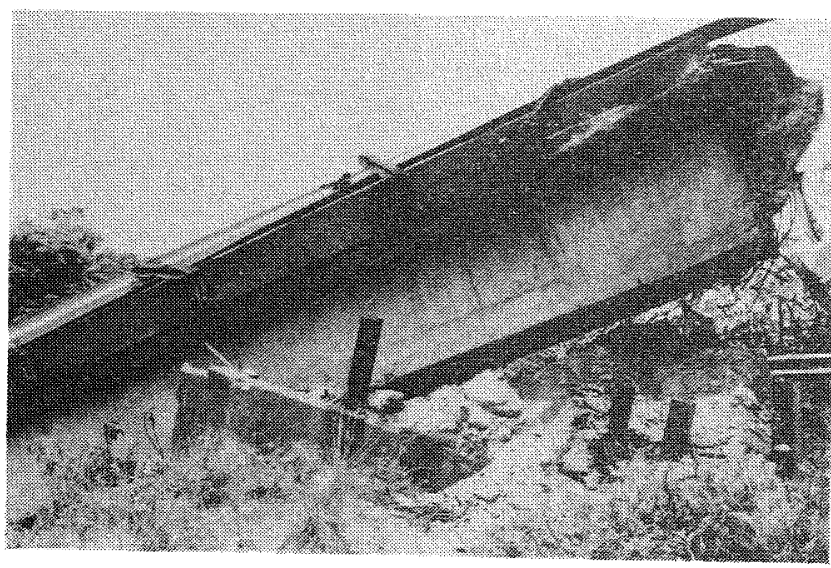

(d) North Span Pushed Up and Over End Abutment.

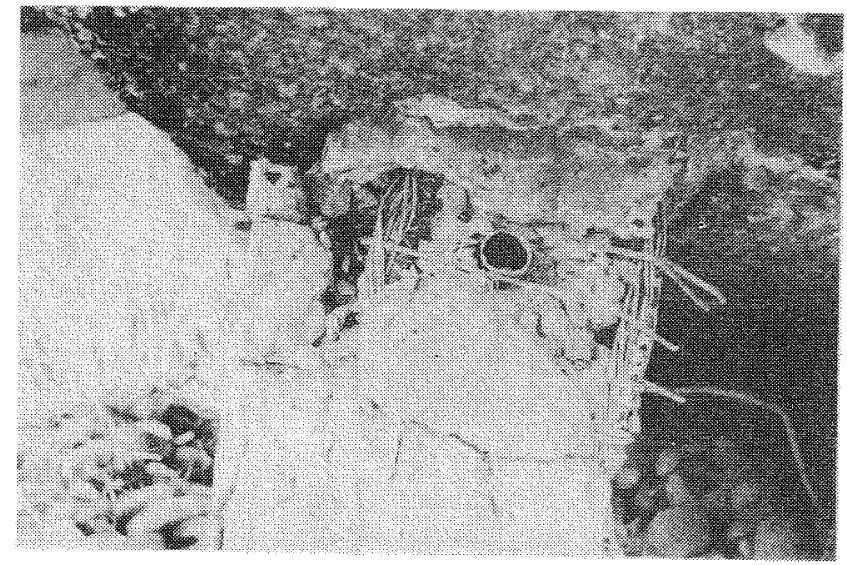

(f) Detail of Pile Flexural Failure. Note poor detailing transverse reinforcement.

FIGURE 15: Damage to Rio Viscaya Bridge (location 10, Figure 1). 


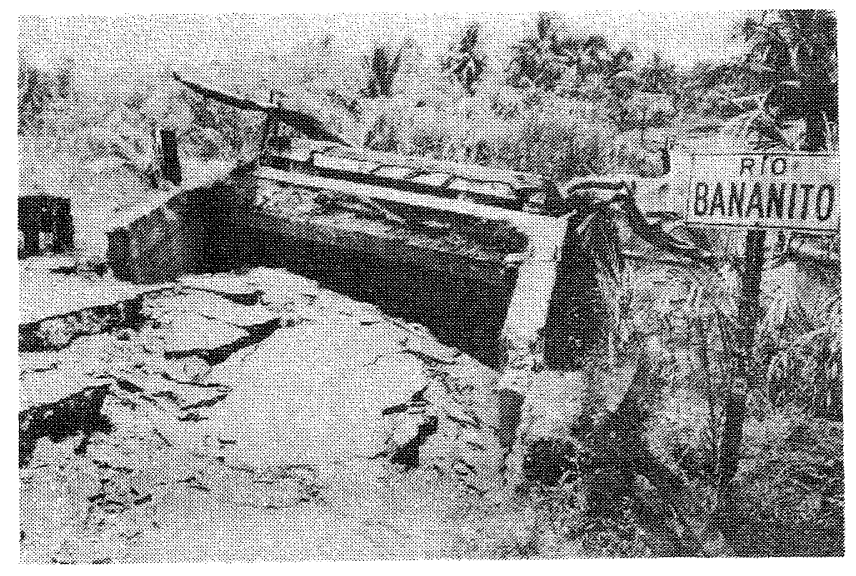

(a) Abutment Slumping and Rotation.

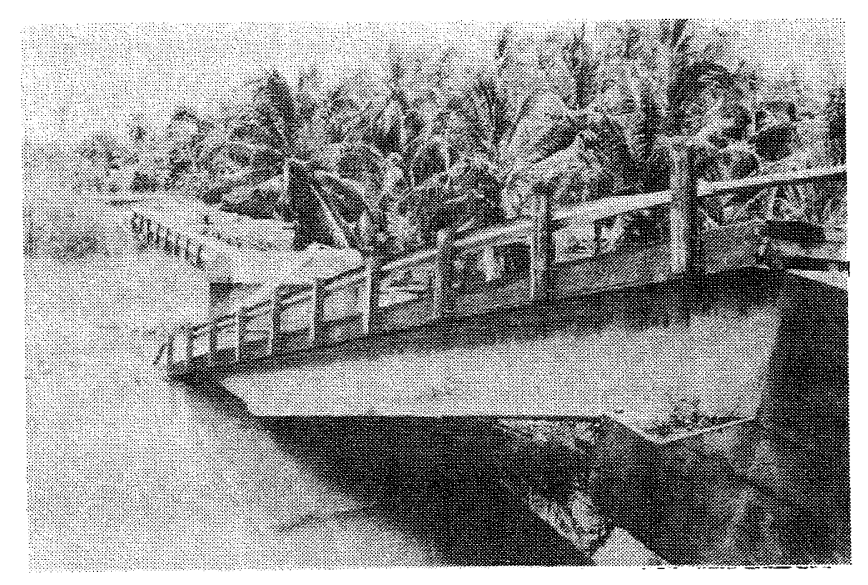

(b) Spans Thrown off Central Pier in Direction of Increasing Skew.

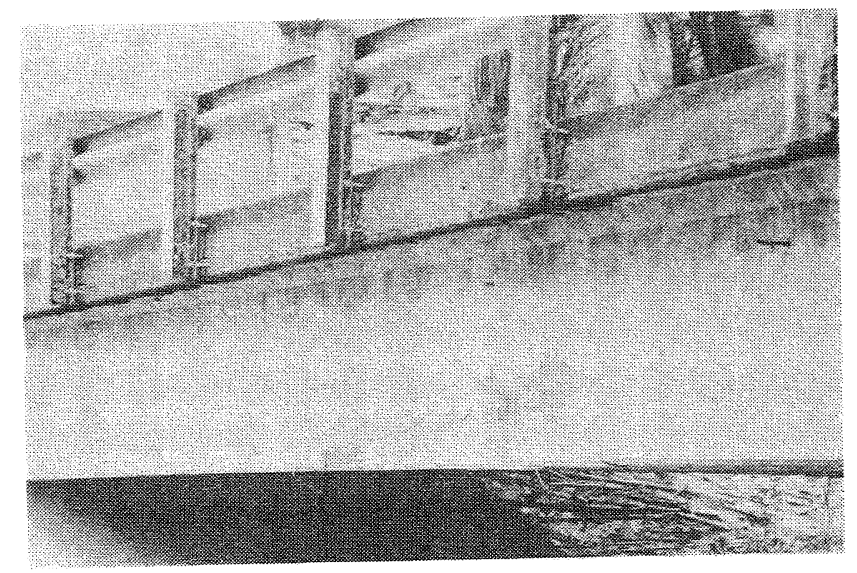

(c) Compression - Shear Failure of I-Girder.

FIGURE 16: Damage to Rio Bananito Bridge - A 2-Span Skewed I-Beam Bridge (location 11, Figure 1).

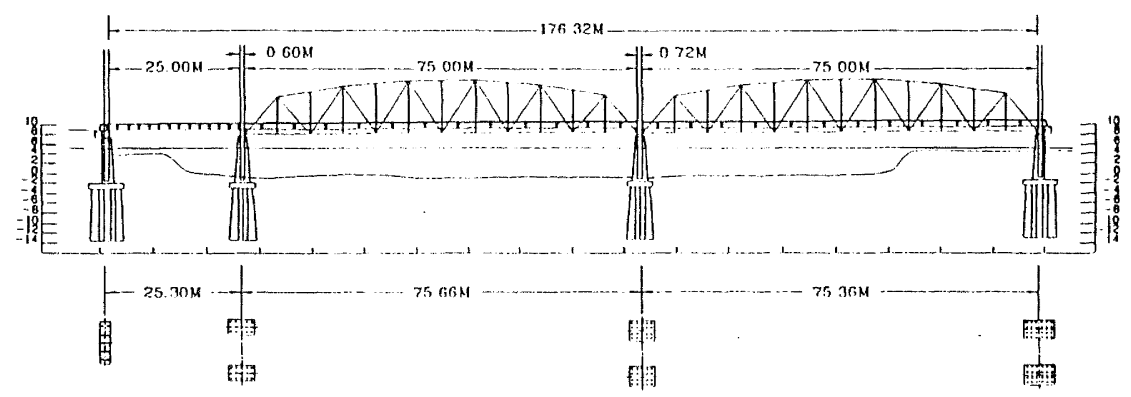

(a) General Dimensions.

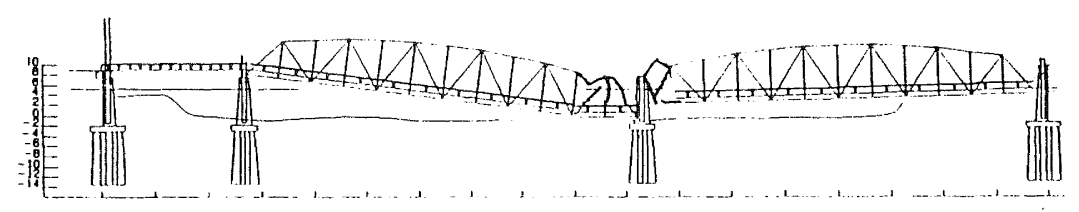

(b) Failure Mode. 


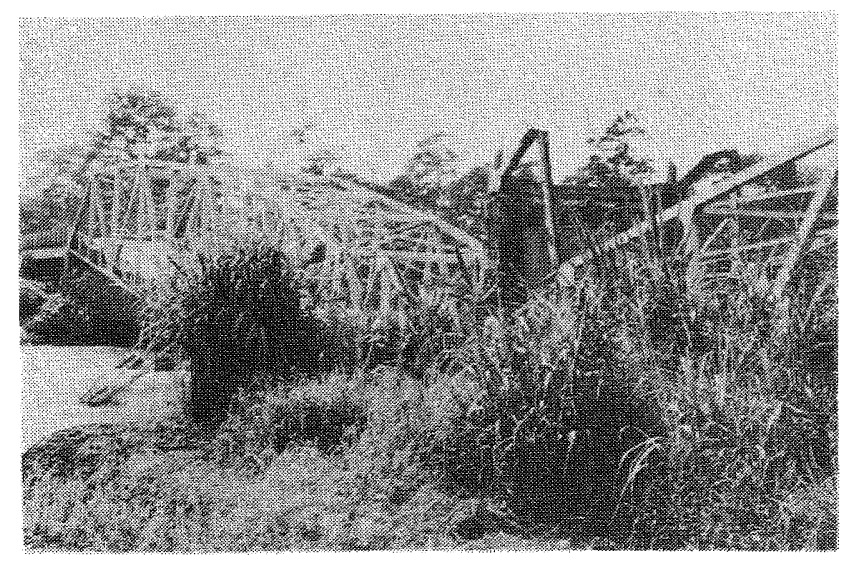

(a) General View from South-West.

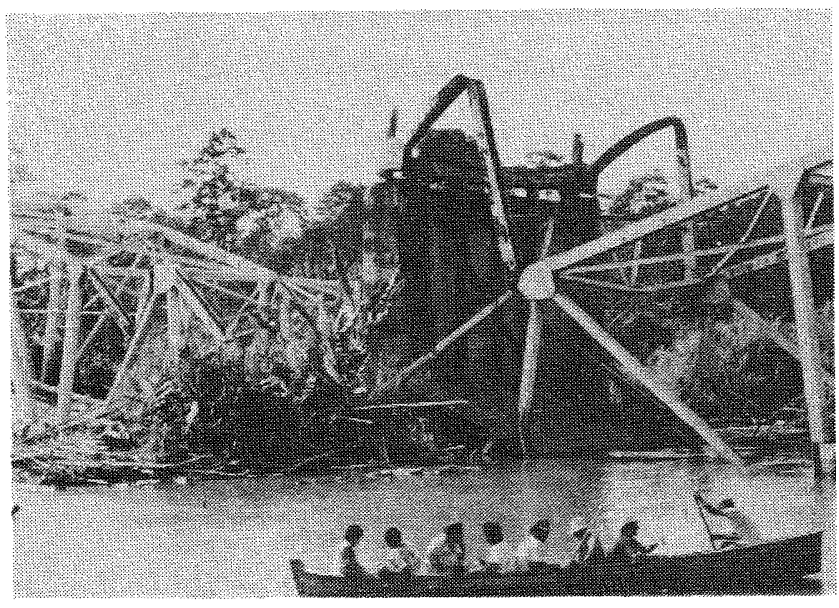

(c) Failure at Central Pier, Viewed from South-West. Note failure of bottom tension chords.

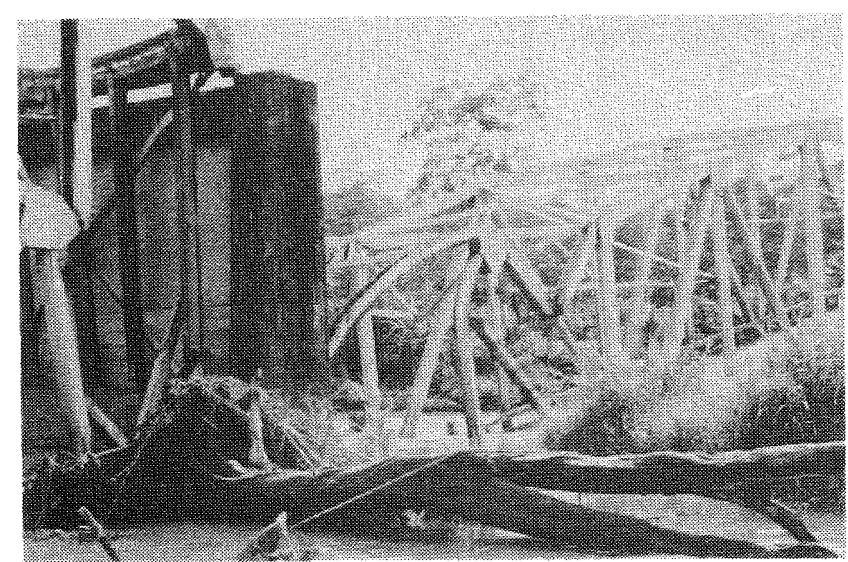

(e) North Span Failure - Damage to truss apparently caused by impact after unseating.

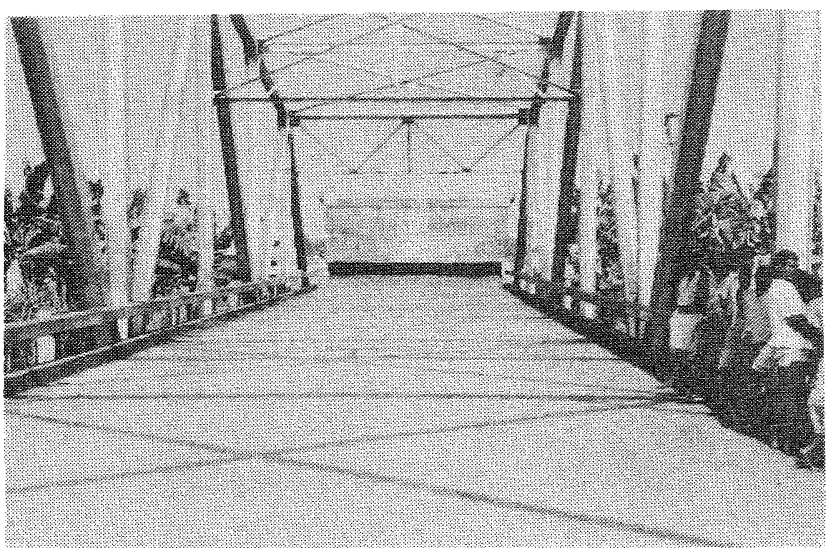

(b) Unseating of South Span off End Abutment Seating.

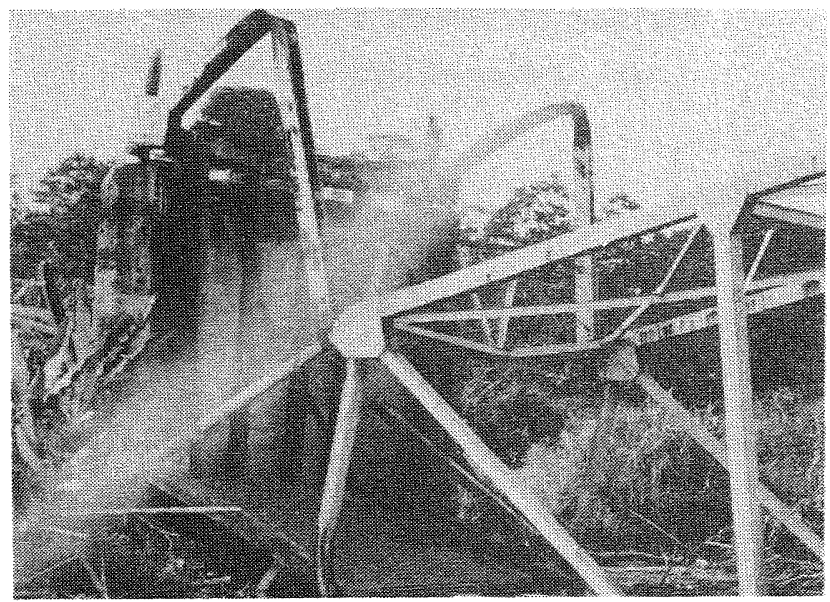

(d) Detail of South Span Collapse.

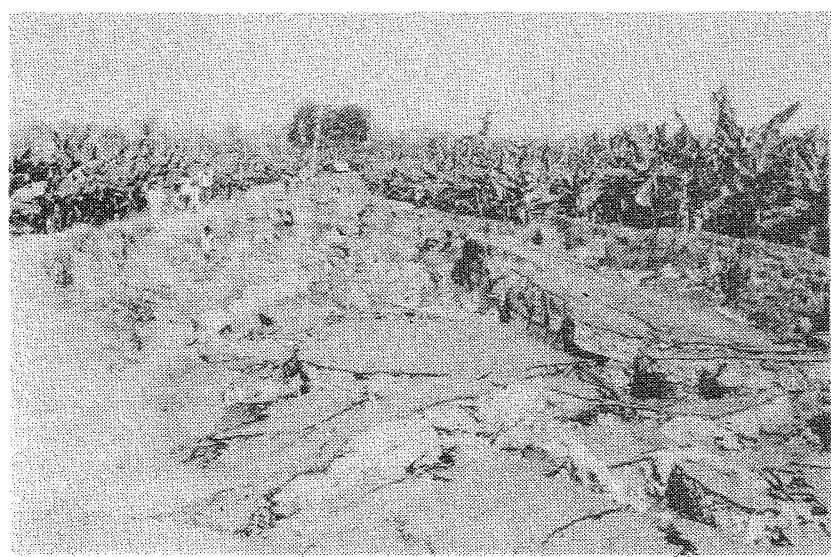

(f) Road Embankment Damage at Rio

Estrella Bridge South Approach, looking South.

FIGURE 18: Damage to Rio Estrella Bridge (location 12,

Figure 1). 


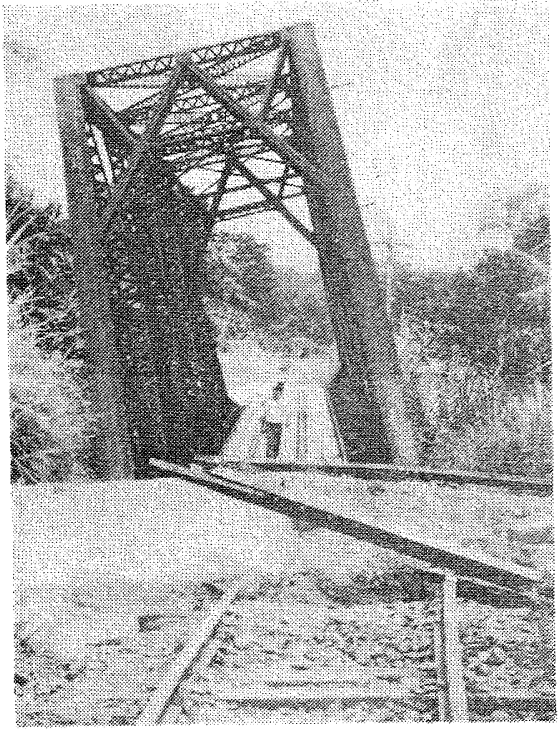

(a) Rotation of Truss to the West.

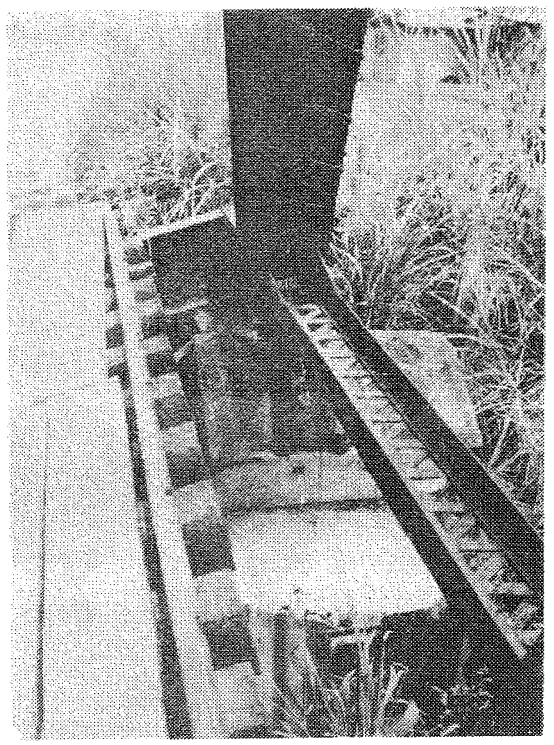

(b) Cast Iron Caisson Rotated Towards River Causing Support Block to Rotate in Opposite Sense. (South abutment).

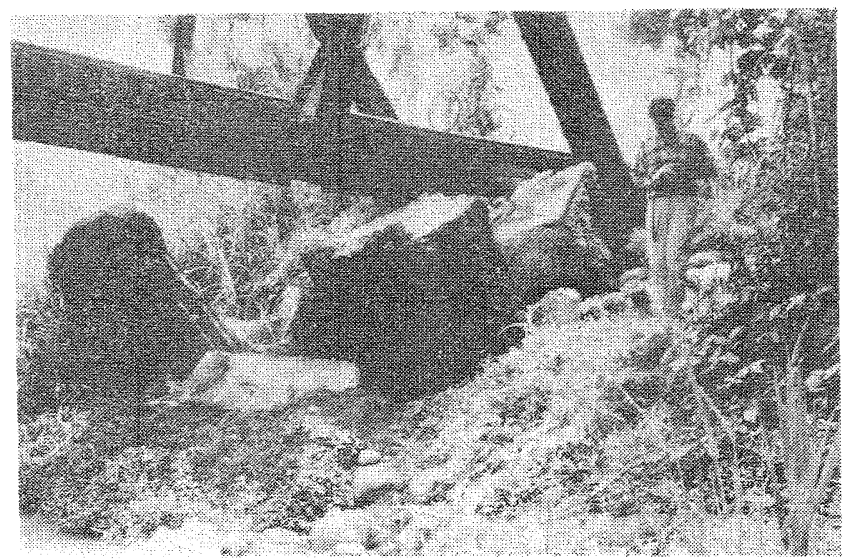

(c) Caissons Rotated Towards River with Support Block Fallen off and behind. (North abutment).

FIGURE 19: Damage to Rio Bananito Sur Rail Bridge (location 13, Figure 1).

The International, a 3-storey reinforced concrete frame structure was on a corner site, and had infilled frames (or possibly shear walls) on the two sides not facing the streets. The lower storey, on the street frontages, was more open to the street than at upper levels, creating a classic combination of torsional eccentricity with soft-story response, almost inevitably resulting in collapse. The plan area was approximately $12 \mathrm{~m} \times 20 \mathrm{~m}$ with 4 frames running at uneven spacing in the short direction, and 3 fames in the long direction. As fig. 20 shows, the frame members were quite large, with $600 \mathrm{~mm} \times 300 \mathrm{~mm}$ columns reinforced with 8 \# bars $(25.4 \mathrm{~mm}$ dia.) longitudinally and $\# 3$ $(9.6 \mathrm{~mm})$ peripheral ties and at $300 \mathrm{~mm}$ centres at the lowest level. The roof was of light corrugated iron and timber. Floors were precast planks with a nominal $50 \mathrm{~mm}$ topping slab, though it was noted that the thickness was up to $100 \mathrm{~mm}$ in places, adding to inertial mass. Beam column knee joints did not have continuity of reinforcement for negative (closing) moments, nor joint shear reinforcement (see Fig.20) and may have contributed to collapse of the upper levels. However, much of the upperlevel damage was the result of rescue operations. As with most of Puerto Limón, the building appeared to be founded on coral. A similar though larger building, the Hotel Acon, two blocks south was essentially undamaged.

The Hotel Las Olas is a considerably larger building, four stories high, consisting of two similar, though not identical structures, each one bay transversely by about 10 bays longitudinally, linked by a central foyer/administration/stairs area of considerable structural irregularity. The wings are founded on concrete pads on the coral, which originally was underwater (hence the name 'Las Olas', which means 'the waves'. The current nickname is Las Rocas, since the uplifted coastline has exposed about $1 \mathrm{~m}$ of coral reef). The south wing had a lower level walkway which was not present in the north wing. 


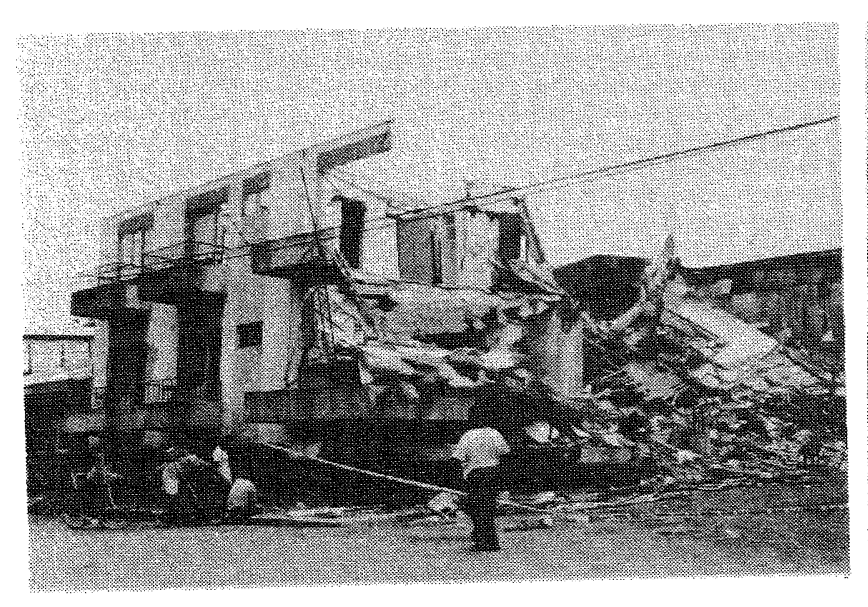

(a) General View.

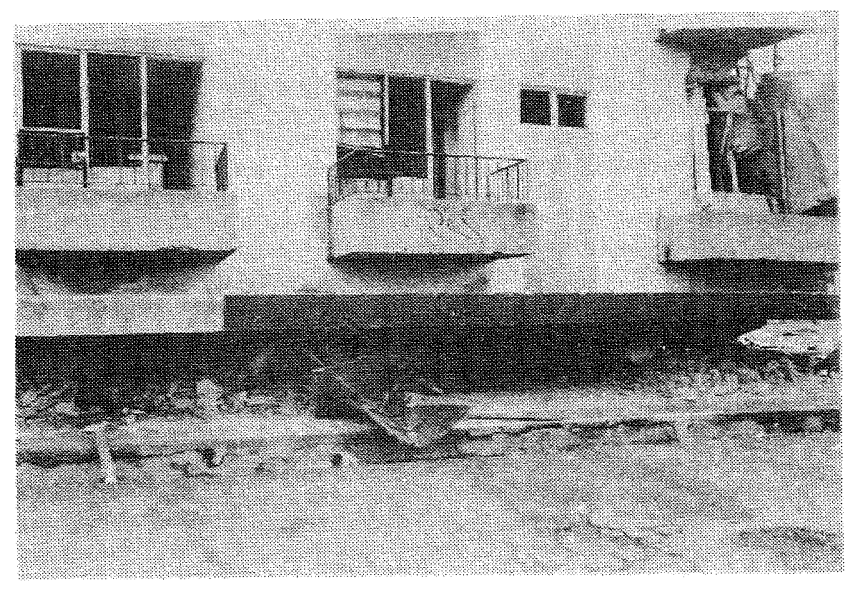

(b) Collapsed Soft Storey.

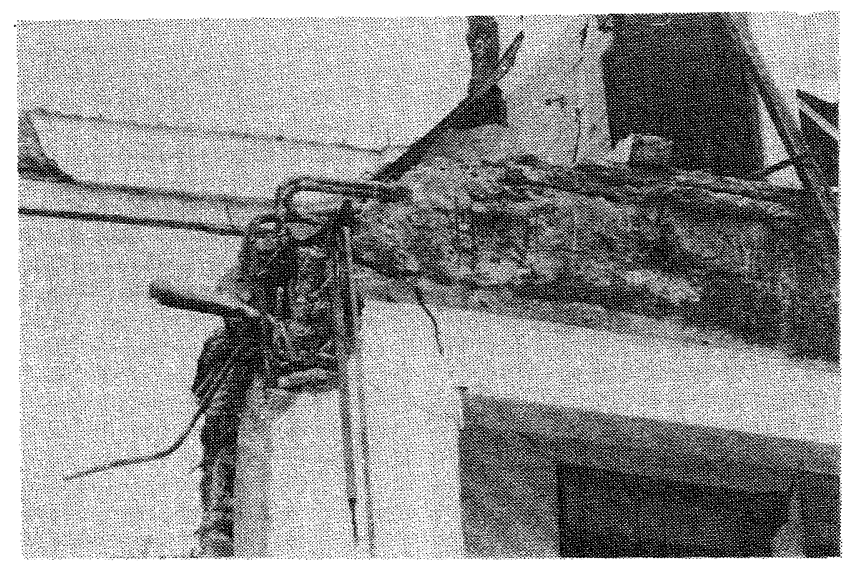

(c) Beam-column Joint Details.

Note discontinuous reinforcement at outside of joint.

FIGURE 20: Failure of Hotel Internacional - Puerto Limón.

The hotel rooms were divided by unreinforced, but grouted, hollow clay tile masonry unanchored to the surrounding structure except by electric wiring, which at some levels prevented total collapse. At the lowest level, the office was infilled on 3 sides with masonry, creating columns which where short in the transverse direction. The two columns on the seaward side collapsed under an earthquake pulse West $\rightarrow$ East causing considerable damage to the central region of the structure. Infill panels at the upper level generally collapsed, frequently onto beds. At the 2 nd floor, the infill collapse was partial. The structural frame at these levels was undamaged. Fig. 21 shows details.

Precast concrete structures appear to be comparatively widely used on the East Coast for industrial use. One rather complex precast chemical factory in the Port of Moin was being extended at the time of collapse. Precast A-frames had been erected and connected longitudinally, though connection to the existing structure was minimal, and the in-situ joints connecting the bases of the A-frame members to the supporting precast buttress walls had not been poured. This structure collapsed totally (see Fig.22). The existing older portion of the factory shows the intended structural system of the extension, which was structurally identical.
A second precast building, apparently intended as a service station auto shop, $3 \mathrm{~km}$ north of Moin was also under construction when the earthquake struck, though the structure was essentially complete. This consisted of 4 precast frames of three pin-jointed members with the column bases founded on pads. Longitudinally the frames were connected at the back wall, but open along the front. The two side walls were each infilled with two prop columns and precast panels fitting into slots in each other and the columns, but without welded connections. The column bases had footing beams between them, but reinforcement was not continuous between the column bases and the footing beam. Under the earthquake the adjacent ground liquified, the side frame columns moved apart about 12 inches opening up a gap in the discontinuous footing beam, and vertical infill panels in the outer bays of the side frames suffered shear failures (see Fig.23). If this building had been on a proper foundation pad with tie beams around the perimeter, it probably would not have suffered damage. 


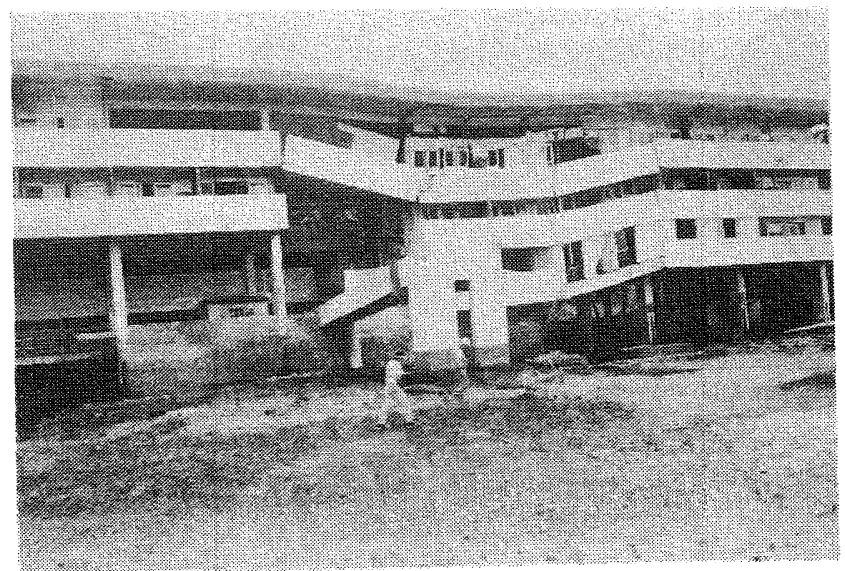

(a) View of Collapsed Portico, also showing uplifted coral reef, formerly below sea level.

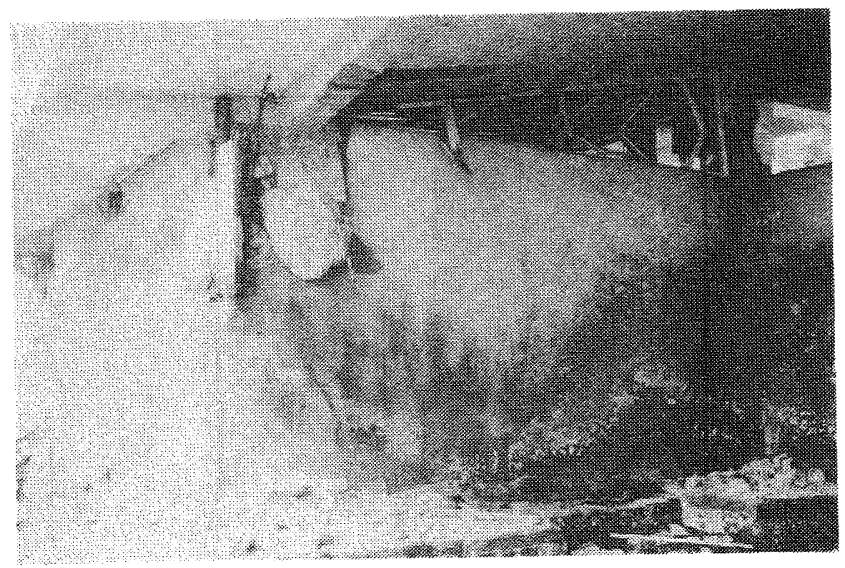

(b) Cause of Collapse - Short Columns at Centre of Building.

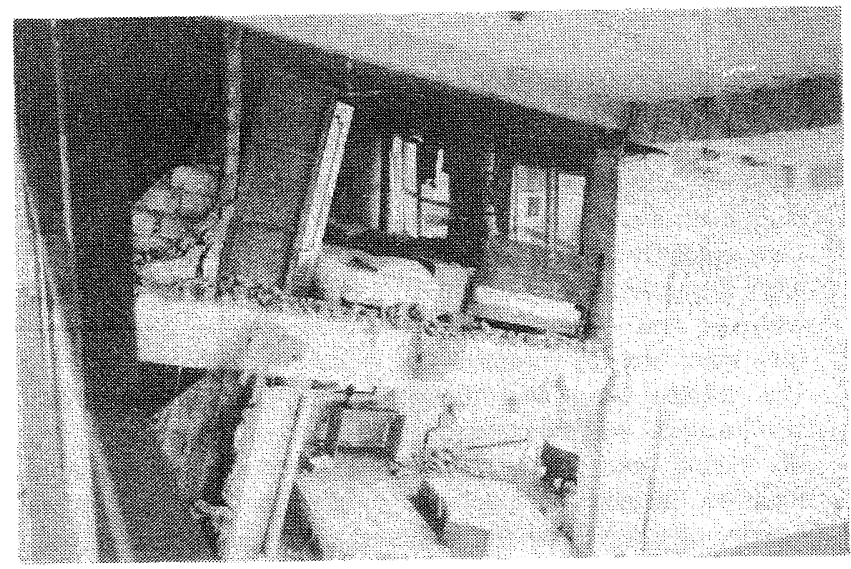

(c) Failure of Masonry Infill Walls.

FIGURE 21: Failure of Hotel Las Olas - Puerto Limón.

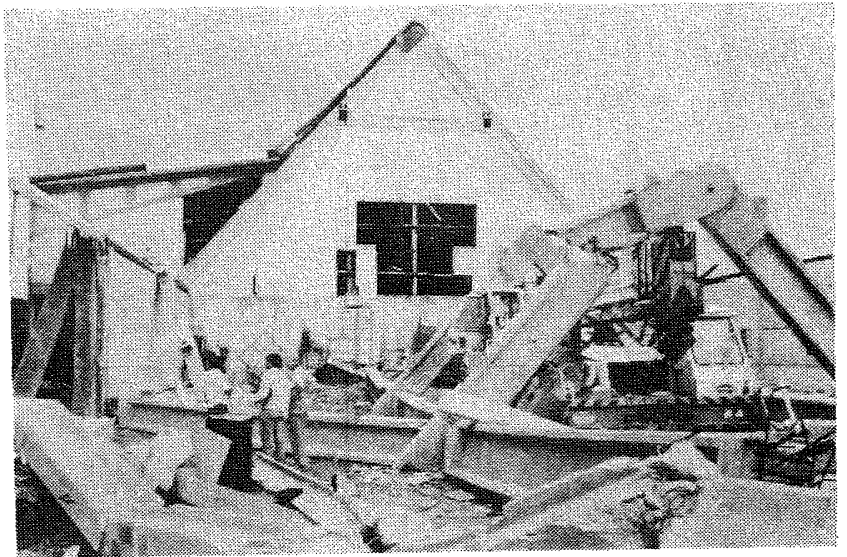

(a) Collapsed A-Frame. Existing identical structure in background.

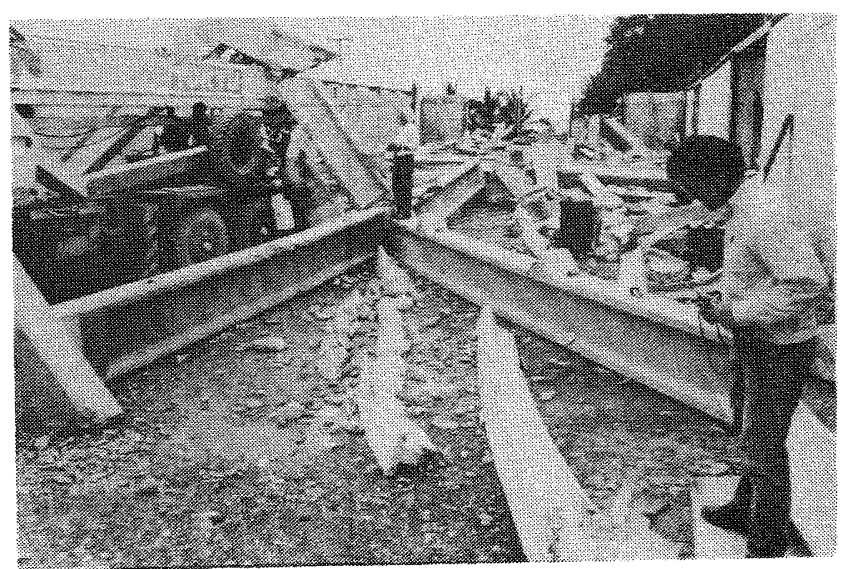

(b) Details of Collapsed Units.

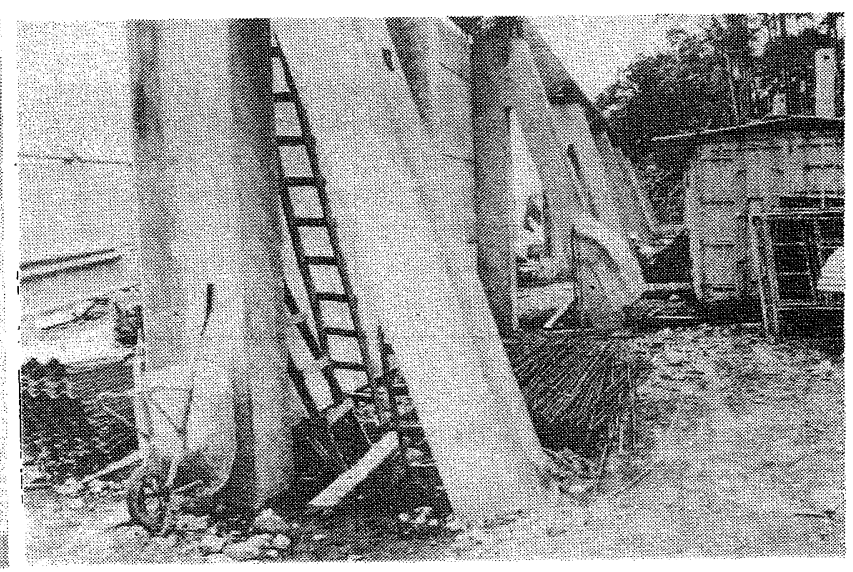

(c) Precast Wall Supports.

FIGURE 22: Precast Warehouse at Moin. Under construction at time of earthquake. 


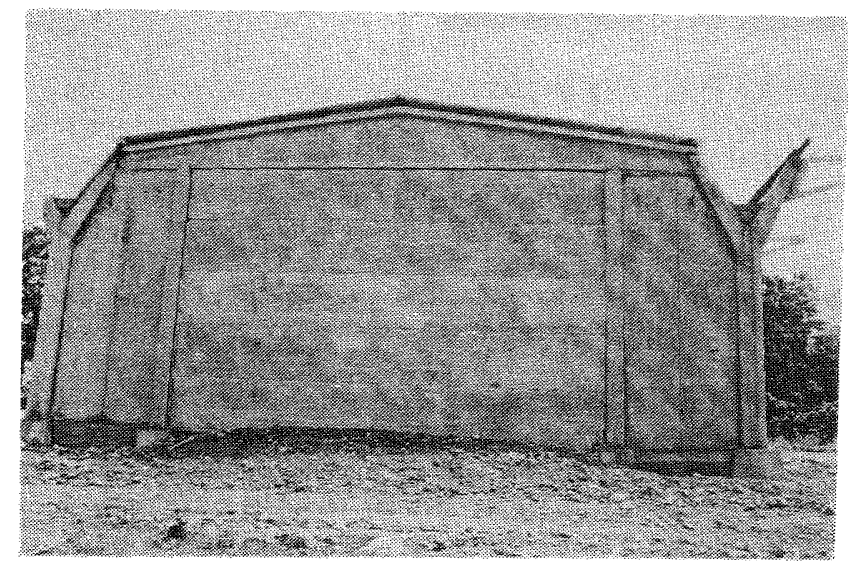

(a) Exterior View.

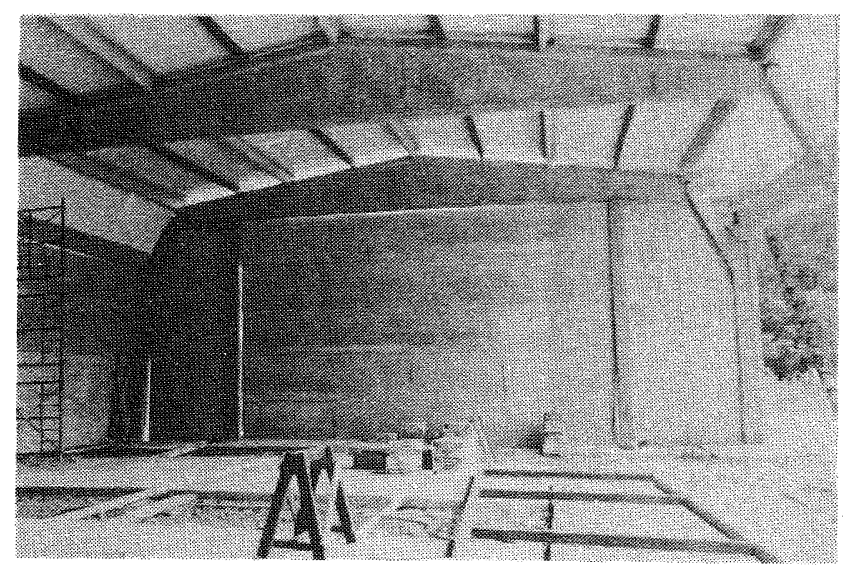

(b) Interior View. Note spreading at foundation level.

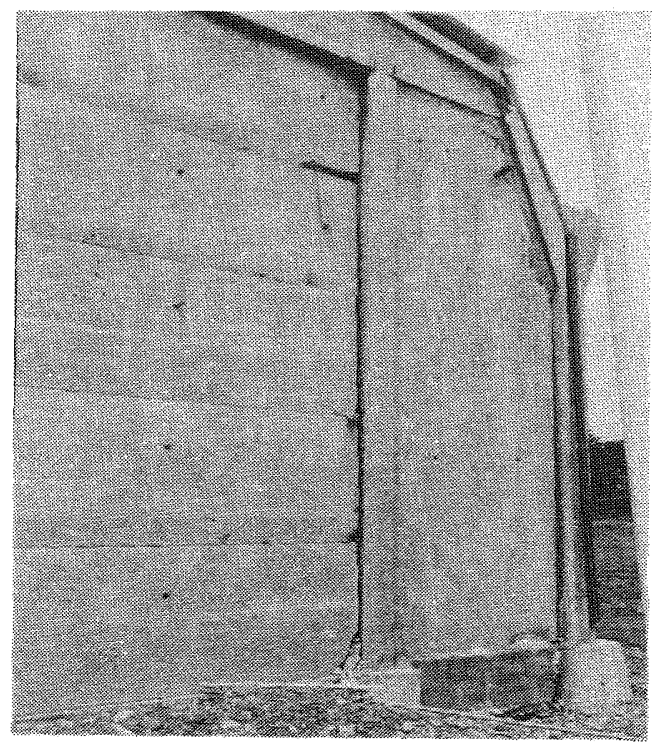

(c) Shear Failure of Precast End Panels.

FIGURE 23: Precast Service Station at Moin (under construction).

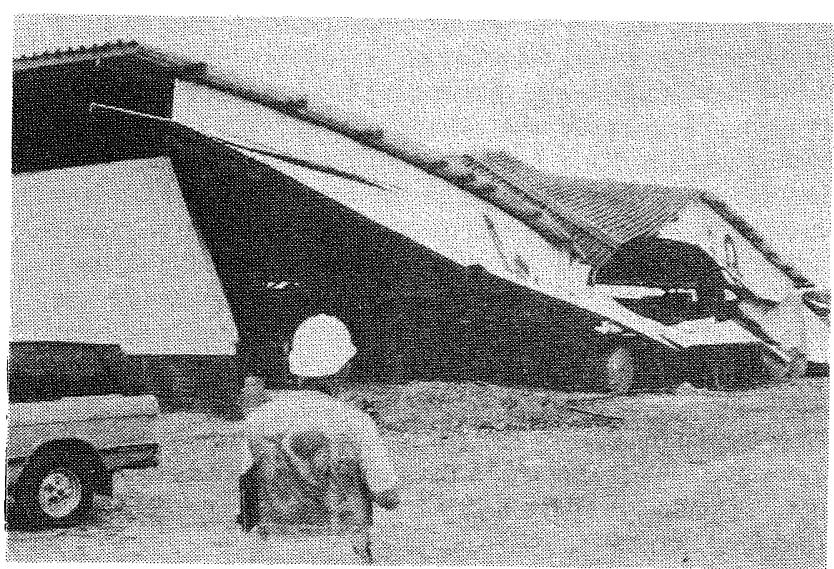

(a) General View.

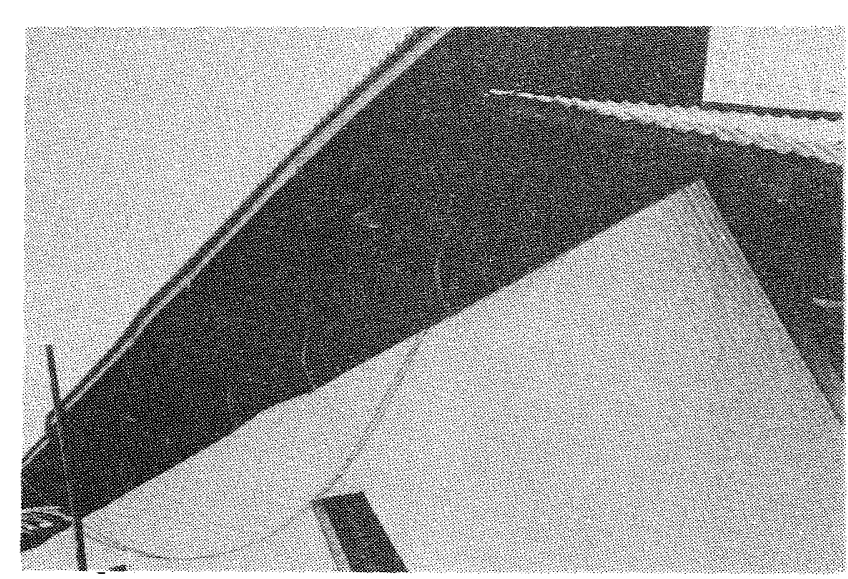

(b) Buckling of Exterior Steel columns.

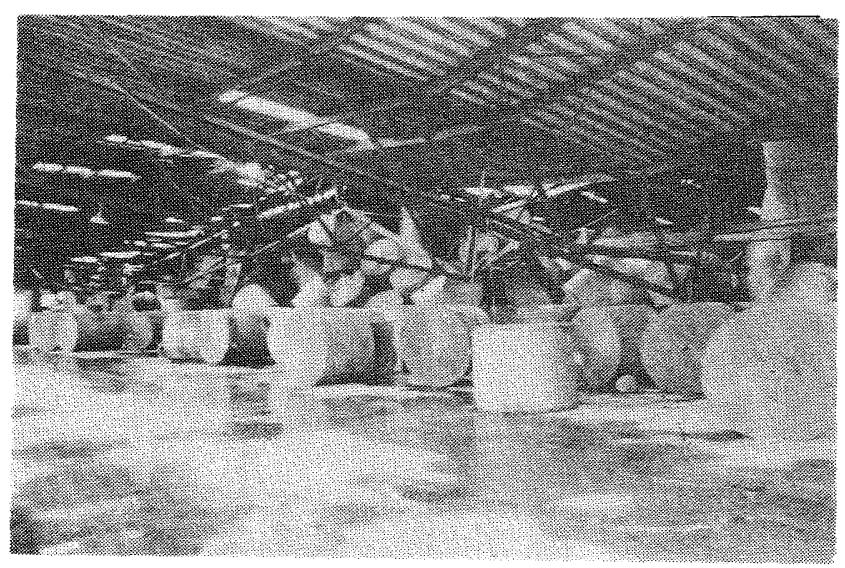

(c) Collapsed Paper Roll Stock Caused Collapse of Internal Columns.

FIGURE 24: Failure of Paper Storage Warehouse - Puerto Limón. 
Two steel factory and storage buildings owned by ENVACO, a cardboard banana-box manufacturer, collapsed (the warehouse) or had significant damage (the factory) as a result of overturning of stacked large paper rolls. The rolls, about $2000 \mathrm{~kg}$ in weight each, about $2 \mathrm{~m}$ dia. $\times 2 \mathrm{~m}$ high, were stacked up to 4 high. In the warehouse they collapsed to the west, again indicating a strong ground movement west to east, and brought down one of the internal steel column support lines of the building (see Fig.24). Less damage was caused to the factory where the boxes were made. The most significant damage here was caused to the reinforced concrete portal surrounding the loading bay in the nonstructural reinforced masonry end wall (Fig. 25a). Note the reinforcement detail connecting the column to the deep top beam. Other damage to the factory included buckling of box steel columns $(200 \times 150 \times 2 \mathrm{~mm})$ supporting a light steel roof (Fig.25b).

\section{Damage to Lifeline Structures}

Damage in the form of extensive elephants-foot buckling was reported by others ${ }^{(1)}$ to small $(10 \mathrm{~m}$ dia. maximum) tanks in a chemical tank farm in Moin. An elevated steel water storage tank at Beverly, about $15 \mathrm{~km}$ south of Limón, totally collapsed. The tank was approximately $4 \mathrm{~mm}$ diameter by $5 \mathrm{~m}$ tall, and reputedly $1 / 2$ full at the time of the earthquake, supported $12 \mathrm{~m}$ above grade on 8 inclined pipe legs. As shown in Fig.26a, the support structure was braced with two levels of circumferential pipes, and diagonal $25 \mathrm{~mm}$ reinforcing cross bracing welded at the centre of the cross, and to end gusset plates. One of the rebar braces suffered a brittle fracture at the connection to the base gusset (see Fig.26b) and may have contributed to the failure, shown in Fig. $26 \mathrm{c}$ by creating torsional eccentricity in the support system.

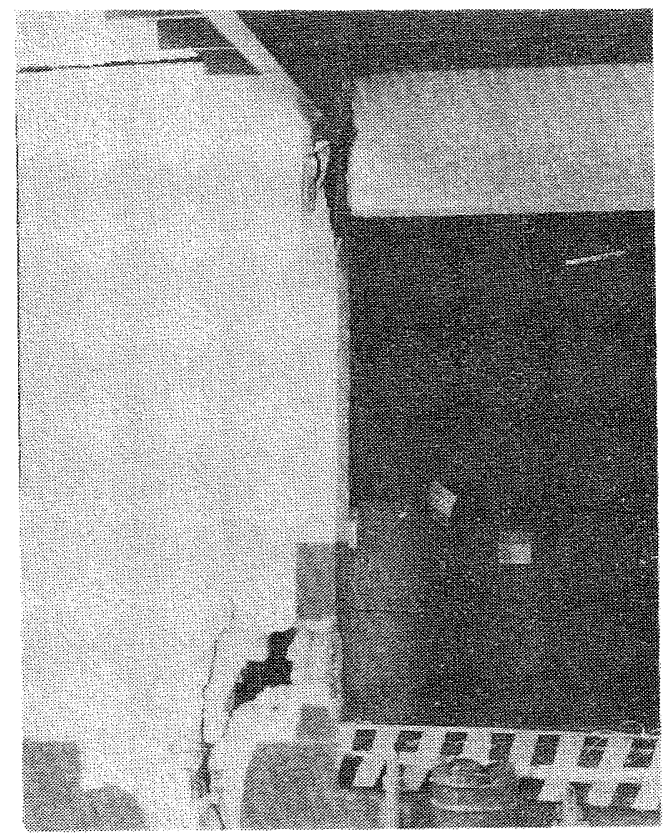

(a) Non Load-Bearing End Wall with Loading Dock.

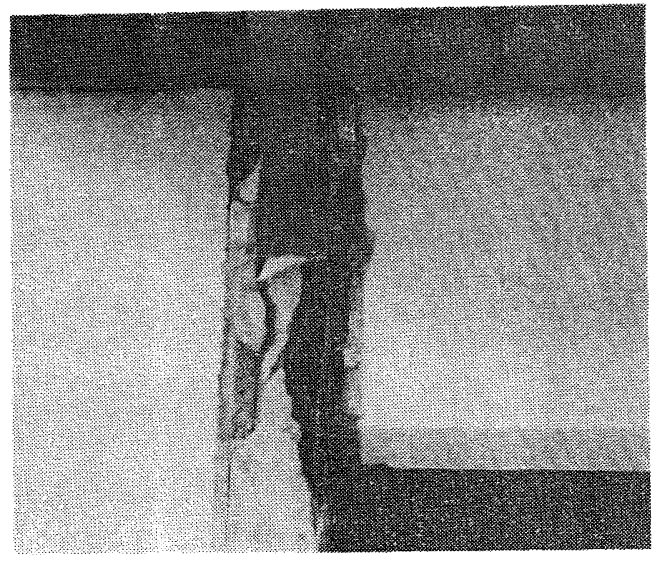

(b) Detail of Beam-Column Connection Above Loading Dock.

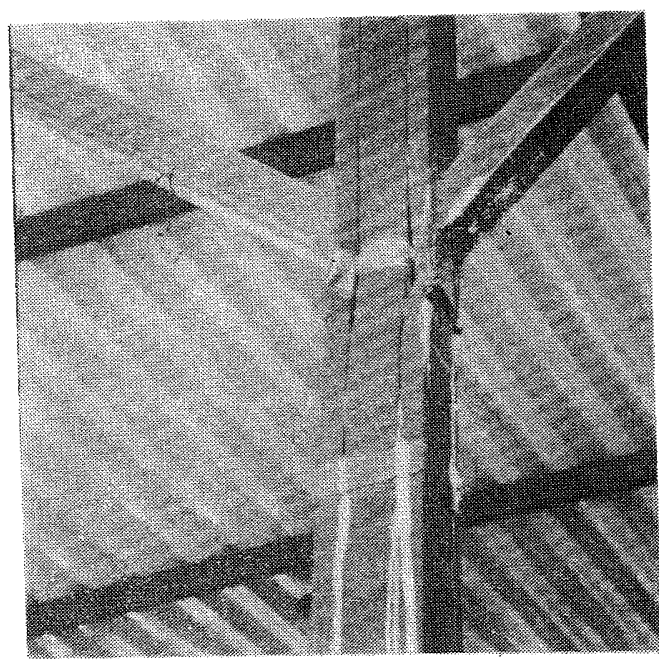

(c) Buckling of Light-Gauge Steel Columns. 


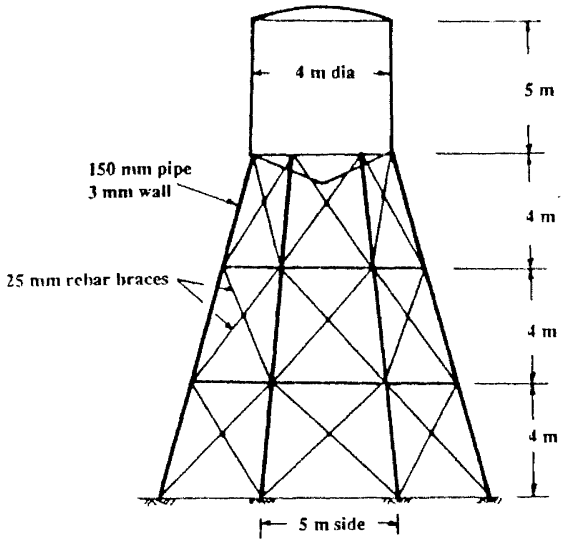

(a) Dimensions - Elevation.

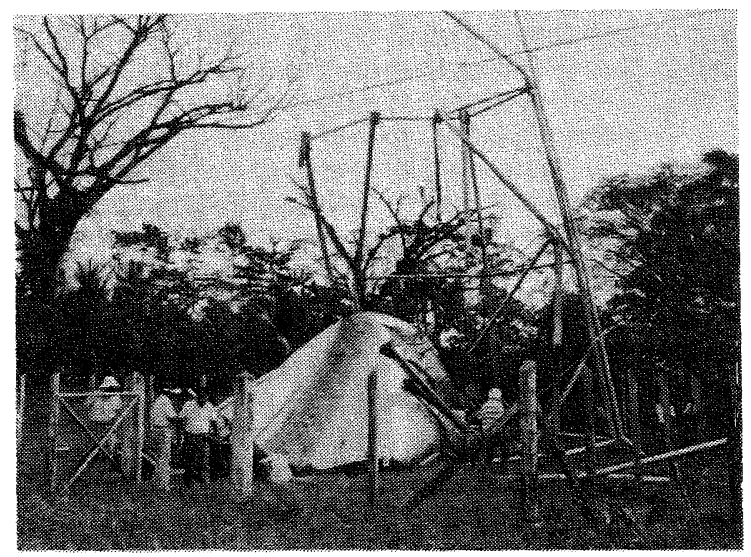

(b) General View of Collapse.

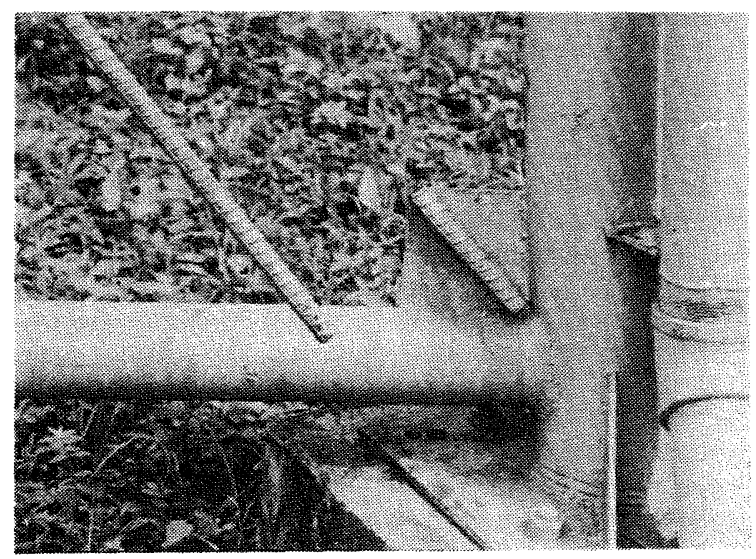

(c) Brittle Fractured Rebar Brace at Weld.

FIGURE 26: Collapsed Steel Water Storage Tank at Beverley.
Wharf structures in Puerto Limón and Moin performed well. In particular the new Muella Alemagne [German Wharf, constructed with aid from West Germanyl appeared structurally undamaged, though there was extensive liquefaction and settlement of fill material adjacent to the wharf, with consequent tilting of light towers supported on the material [Fig.27].

Electric power standards adjacent to a railway line near Moin failed as a consequence of poor support and anchorage details [Fig.28]. Water supply and power were disrupted throughout the Limón/Moin region. However, by the time the reconnaissance team arrived, 6 days after the earthquake, electric power had been restored to almost all areas. By the time the team left, water supply had been reconnected to most parts, with the hotel the team was staying at being a rare exception.

An elevated oil pipeline running from Limón to San José was the sole means of supplying oil to the capital from the Port of Moin. This pipeline was subjected to considerable distortion as a consequence of longitudinal ground deformations, as is apparent in Fig.11a, and in Fig.29. Despite the span collapse of the Rio Chirripo Bridge, and the subsequent infilling with gravel, shown in Fig.11b, the pipeline was not fractured. In Fig.29, the left pipe has buckled, and displaced laterally off its saddle support, and onto the other pipeline. Although the elevation of the pipeline resulted in little support against buckling, it may have saved the pipeline from fracture, which might have been expected if the pipeline had been constrained to follow the longitudinal ground displacements by being buried.

In general, despite wide spread complaints about bureaucratic inefficiencies, it appeared that at least at the local level, response to reestablish lifelines was effective. Key road links between San José and Limón were reopened within days of the earthquake, despite large areas of road requiring bulldozing and filling of crevices. An alternative inland link from Limón to Bribri was almost immediately opened, and sufficient work done to allow the coastal road to be opened to heavy traffic using river fords and repaired roads by 12 days after the earthquake. As noted above, power and water were also speedily reconnected. Most criticisms were directed towards the distribution (or lack thereof) of food and potable water in the first week to 10 days after the earthquake.

\section{CONCLUSIONS}

The most structurally significant damage caused by the Costa Rican earthquake of April 22 was the extensive damage to bridges, primarily resulting from gross soil deformations [slumping and liquefaction]. Structural aspects seemed to contribute to the damage, in that pile lengths were probably inadequate (typically only about $19-20 \mathrm{~m}$ long) and not founded on firm and stable materials. Also, most of the bridges lacked redundancy. Spans were simply supported at abutments and at interior spans, so rotation of abutments or internal bents were not resisted by structural action. Span support lengths were generally inadequate at internal piers, but reasonably generous at abutments. Some bridges had rigid restrainers between spans, allowing only rotational freedom about the horizontal axis, but no restrainers between ends of spans and abutments. It is felt that continuity of spans, integral span/internal bent details, and possibly integral span/abutment details might have reduced the extent of damage, and particularly reduced the incidence of collapse. 
Damage to other structures were similar to those experienced in other recent earthquakes, and were generally due to poor structural systems, including soft stories and short columns caused by partial height infill and poor structural details.

\section{ACKNOWLEDGEMENTS}

This report is based on the observations of the writer alone, and should not be construed to represent the consensus of the EERI reconnaissance team. However, the writer would be remiss if he did not acknowledge the importance of discussion with the other team members: Gene Cole (team leader), J.P. Singh, B.E. Aquirre, D. Ballantyne, K. Jacob, A. Lavell, 'Johnny' Bermudez, Guillermo Santana and other Costa Rican engineers in formulating opinions expressed above. Also useful discussions with others on separate reconnaissances are gratefully acknowledged, including discussion with Mariane Phipps of Henry Degenkolb Associates, Ron Hamburger of EQE Engineering, and Ray Zelinski and Steve Mellon of the California Department of Transportation.

Permission of the EERI to produce the bridge sketches of Figs.13a, 14a, and 17a is gratefully acknowledged.

\section{REFERENCES}

1. EERI Spectra 'Costa Rica Earthquake Reconnaissance Report', Supplement B to Volume 7, October 1991, 127pp.

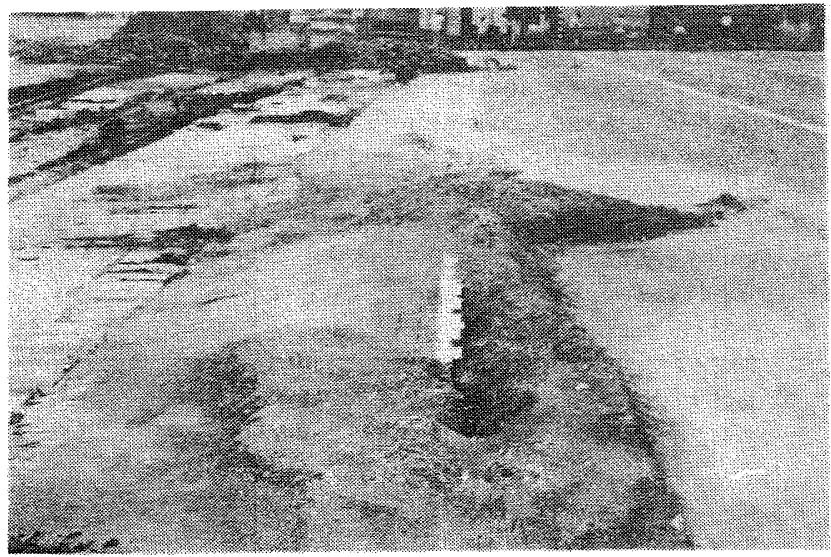

FIGURE 27: Liquefaction Damage to Muelia Alemagne (German Wharf) - Puerto Limón.

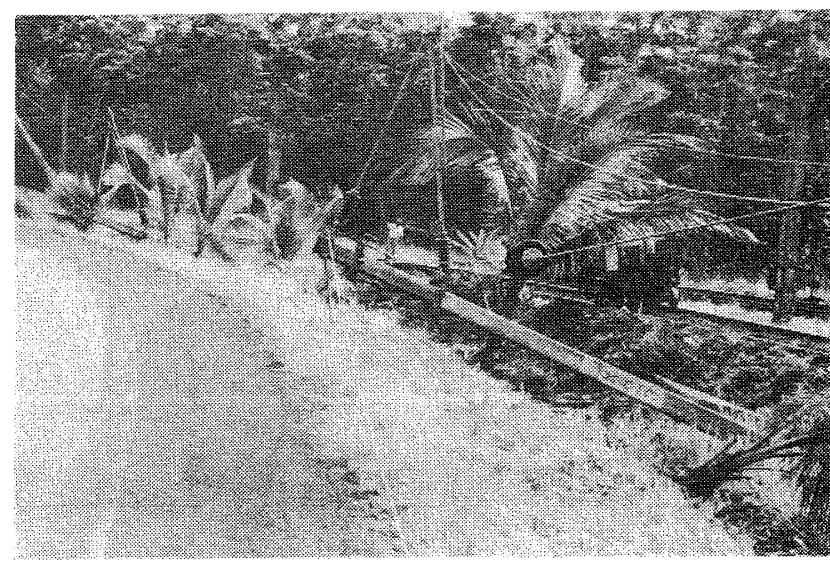

FIGURE 28: Overturned Electricity Standards by Railroad Track at Moin.

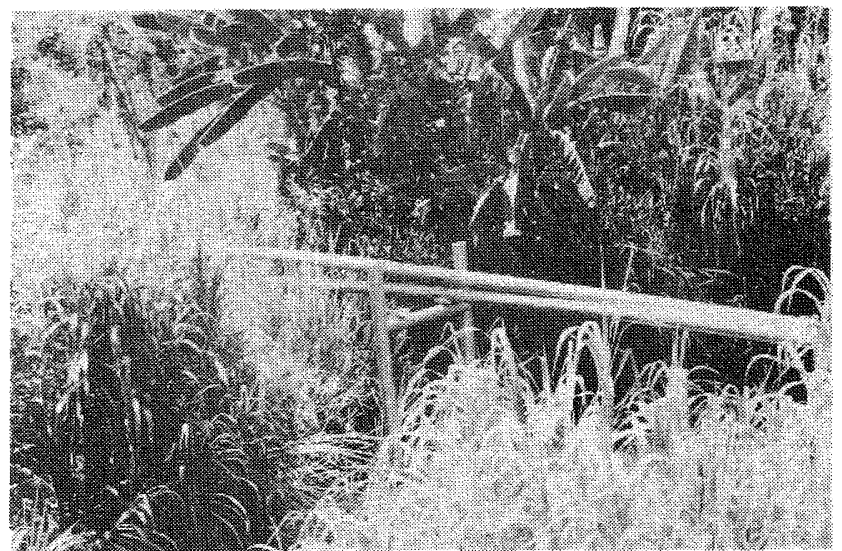

FIGURE 29: Buckling of Elevated Oil Pipeline. (Fracture would probably have happened if the pipeline had been buried). 